\title{
Do fodder import and credit loans lead to climate resiliency in the pastoral social-ecological system of Inner Mongolia?
}

\author{
$\underline{\text { Yanbo } L i i^{1,2} \text { and Wenjun } \mathrm{Li}^{2}}$
}

\begin{abstract}
Mainstream policies encourage pastoralists to apply credit loans and input exogenous fodder to alleviate the stress caused by climatic variability and uncertainty. Such external inputs induce new driving forces to the coupled pastoral social-ecological system (SES), but their long-term impacts are not fully understood. Taking Sonid Left Banner of Inner Mongolia as a case study area, we applied an agent-based model and Monte Carlo simulation to evaluate the impacts of fodder import and credit loans on the resilience of pastoral SES in terms of pastoralist household livelihood, livestock production, and rangeland health. The results showed that the strategy of importing fodder only in natural disaster years could make the pastoral SES more resilient to climatic variability, while frequent importing of fodder in climatically normal years would increase the vulnerability of the pastoral SES. Credit loans could enhance the resilience of the pastoral SES in general if fodder is not imported or only imported in disaster years, but could reduce the resilience if fodder is imported frequently. Our findings revealed several differences with previous research on fodder input and credit loan effects, indicating that relevant policies should be holistically evaluated from the perspective of social-ecological systems.
\end{abstract}

Key Words: agent-based model; credit loans; fodder import; Inner Mongolia; Monte-Carlo simulation; pastoral social-ecological system; resilience

\section{INTRODUCTION}

Pastoral systems in arid and semiarid areas are characterized and shaped by dramatic climatic variability (Behnke and Mortimore 2016). This characteristic is usually perceived as inherited vulnerability (Smit and Wandel 2006, Reynolds et al. 2007, Kraetli and Schareika 2010). Effective adaptation to the variable and changing climate is critical to the ability to sustain the resilience of the pastoral social-ecological systems (SES). Traditionally, pastoralists used mobility, livelihood diversification, community pooling, and stocking strategies to manage this variability (Scoones 1994, Xie and Li 2008, Agrawal 2010) and maintained resilient pastoral SESs (Fernández-Giménez and Swift, 2003). However, influenced by land privatization and subdivision (Fernández-Giménez 2001, Li et al. 2007, Li and Huntsinger 2011), as well as policy interventions (Gongbuzeren et al. 2015), traditional approaches are increasingly difficult to practice (Zhang et al. 2013). Instead, pastoralists gradually turn to depend on market exchange strategies (Hazell and Hess 2010, Wang 2011, Karimi et al. 2018), such as purchasing fodder and borrowing credit loans during times of scarcity. These new strategies have been widely observed in pastoral areas of China (Han 2011, Hou et al. 2012, Wang et al. 2013, Zhang et al. 2018, Gongbuzeren et al. 2020), as well as in Mongolia (Ahearn 2018), middle Asia (Karimi et al. 2018), West Asia, and in the North Africa region (Thornton et al. 2009, Hazell and Hess 2010) even in average and good years.

Impacts of fodder imports and credit loans on pastoral SESs are not fully understood. Theoretically, import of fodder should help to buffer the system against climatic variability through stabilizing production (Horn et al. 2003) and conserving critical assets (Müller et al. 2015). However, reports of positive outcomes are scarce, while more attention has been given to the negative ecological consequences. For example, some empirical studies reported that the import of fodder in the steppe region of North
Asia in cold seasons may increase the risk of rangeland degradation (Seligman and Perevolotsky 1994, Kerven 2004, Wang 2006, Briske et al. 2015) by increasing in stocking intensity. Other studies in the West Asia and North Africa region reported that supplementing feeding may lead to overgrazing during the dry seasons, reduction of the natural seeding of annual pasture species, disturbance of the soil, and may contribute to wind erosion (Hazell 2000) and a conversion of pasture to farmland for feed cultivation (Hazell and Hess 2010). Meanwhile, purchasing fodder increased the financial burden of pastoralists (Han 2011, Zhang et al. 2018) or the government, if subsidies were provided (Hazell and Hess 2010). However, in-depth studies focusing on impacts of supplementary feeding found complex results. Jimoh et al. (2020) found no correlation between stocking rate and hay importation in Inner Mongolia. Two modeling studies in Morocco revealed that impacts of supplementary feeding depended on the purpose and timing of feeding strategies, the features and context of the production system, and that reasonable supplementary feeding strategies may increase the resilience of pastoral SES (Müller et al. 2015, Schulze et al. 2016).

Although positive impacts of credit loans on poverty alleviation (World Bank 2007), rural development (Hannig and Jansen 2010, Luan and Bauer 2016), and women empowerment (Dupas and Robinson 2013, World Bank 2014) have been reported, recent studies also showed that credit loan services generated complicated outcomes in different contexts (Gongbuzeren et al. 2020), and may increase vulnerability of poor pastoral households facing natural disasters and market fluctuations (Barrett and Luseno 2004, Sneath 2012, Murphy 2018, Zhang et al. 2018). These findings suggested that import of fodder and credit was likely to make the system more vulnerable to climate variability, but the decision makers and mainstream academic communities have yet to realize this.

${ }^{1}$ Institute of International Rivers and Eco-Security, Yunnan University, Kunming, China, ${ }^{2}$ College of Environmental Sciences and Engineering, Peking University, Beijing, China 
Particularly, current understanding of impacts of fodder import and credit loans is based on short-term case studies of one- or two-year duration confounded with natural disaster events (except for Müller et al. 2015, Schulze et al. 2016). In pastoral systems, changes in livestock populations and household responses are sensitive to climatic patterns (Boone et al. 2011). Herd size and structure, and household cash flow in any one year are highly dependent on the production conditions in previous years. Therefore, the impacts of fodder input and credit loans from one year may extend to the following several years, including both good and bad climatic years. Several modeling studies revealed complex impacts of supplementary feeding in Morocco (Müller et al. 2015, Schulze et al. 2016), but similar studies are lacking in North Asia where drought and snow disasters intertwine. Therefore, further comprehensive and long-term studies are necessary to understand the impacts of fodder input and credit loans in pastoral areas for better policy design to manage rangeland sustainably.

We used an arid rangeland of Sonid Left Banner of Inner Mongolia of China as a case study, and applied an agent-based model and Monte-Carlo simulations to assess the impacts of fodder input and credit loans on the resilience of a pastoral SES. Our findings contribute to knowledge-based policy making of pastoral SESs.

\section{METHODS}

\section{Study area}

Sonid Left Banner (SLB) is situated in the northwestern part of Xilingol of Inner Mongolia, China. The average annual precipitation in SLB is $198 \mathrm{~mm}$, and the average evaporation is $2458 \mathrm{~mm}$ (Compiling Committee of Annals of Sonid Left Banner 2004). Precipitation is concentrated from June to August and the intra-annual variability is significant. Based on meteorological records of SLB for 1956 to 2012, annual rainfall is $191 \pm 52 \mathrm{~mm}$, and winter precipitation (December to March, mostly snow) is $8.54 \pm 4.80 \mathrm{~mm}$. The year can be roughly divided into the warm (April to September; also the growing season of forages) and the cold season (October to March) based on temperature and availability of forage on pasture. Natural disasters are very common in this area. Ten severe droughts and 12 snow disasters were recorded during 1957 to 2006, with the frequency of one disaster every 4.5 years (Xie and Li 2008). The ecosystem is mainly typical steppe and desert-steppe. The main livestock raised by pastoralists is sheep, as well as some goats and cattle.

Traditionally, pastoralists practiced flexible and overlapping land tenure (Xie and Li 2008). They moved with their livestock for hundreds of kilometers, tracking the variability of forage and water resources and avoiding bad weather; when drought or snow disasters occurred, they moved their livestock quickly to the less impacted areas (Xie and Li 2008). Since the 1950s, the rangelands have been collectively owned by the gacha (village in Mongolian), and were first contracted to groups of households in 1984, and finally to individual households in 1997. Since then, individual households have managed their own contracted pastures, which are usually around 67 ha to raise livestock. To reserve some forage for harsh winters, pastoralists usually divide their pasture into warm-season (WSP) and cold-season pasture (CSP). The CSP is only used for grazing in wintertime, and the residues on WSP could be grazed in the cold season as well. It has been increasingly difficult to use long-distance mobility strategies to manage disasters (Li and Huntsinger 2011). Nowadays, pastoralists move to rental pastures temporarily only when serious droughts occur, and increasingly rely on purchasing fodder to feed their livestock during the cold season even in the normal years, but especially in disaster years. Such demands drive expansion of the fodder market, facilitating a further dependence of pastoralists on more fodder inputs.

Stocking strategies remain important in efforts to adapt to climate variability. Pastoralists carefully select and sell some livestock to adjust and optimize the size and structure of their herd in the autumn, with consideration of cash demands for living and production expenses, availability of pasture forage, and purchasing of fodder. Stocking decision is a trade-off between production profits and herd size. Pastoralists slaughter or sell old and sick livestock to reduce potential mortality, and most of the male livestock to reduce fodder consumption in the harsh winters. Simultaneously, they try to maximize herd size for a quick recovery after disasters (Ellis and Swift 1988, Allsopp et al. 2007, Harris 2010). If necessary, extra livestock that may include breeding ewes are carefully selected and sold to balance the availability of and demand for forage and fodder, and meet the cash demand by the household. Buying livestock is not common among pastoralists in our study area. Only good breeding ewes or rams are bought occasionally.

\section{Design of the study}

The study was designed as shown in Figure 1. First, we constructed an agent-based model (ABM) to simulate the dynamics of herd and cash flow of a pastoral household. Three different fodder strategies were applied in the ABM to simulate the impacts of different supplementary feeding strategies. Second, we ran a Monte-Carlo simulation to determine the distribution of indicator values of livelihood, production, and ecological impacts in stochastic climate. Third, the outcomes with different strategies were compared to estimate the impacts of fodder input. Then, we repeated the previous steps with varying amounts of available loans. The outcomes were compared to those with no credit loan for each fodder strategy to estimate the impacts of credit loans. Finally, as livestock prices may affect the results, we ran the simulation for different livestock price scenarios to test the robustness of the results.

Fig. 1. The framework of the study.

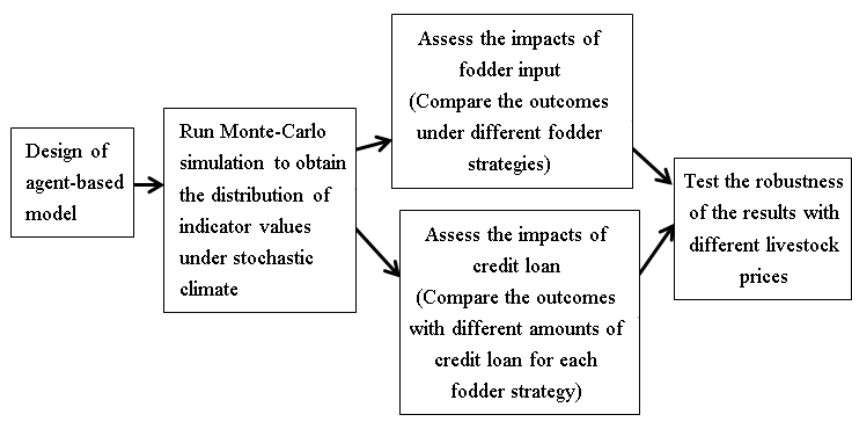


The details are presented below.

\section{Fodder strategy and decision-making rules}

To estimate the impacts of fodder input, three fodder strategies with different levels of fodder input were applied: (a) no exogenous fodder input (NIF), (b) input fodder only in disaster years (IFDY), and (c) frequent input of fodder (FIF) whenever a forage gap occurred, regardless of year type. The decision rules for each fodder strategy are shown in Table 1, respectively.

Table 1. Three fodder strategies and the corresponding rules.

\begin{tabular}{|c|c|c|}
\hline Strategies & Decisions & Rules of decision making \\
\hline $\begin{array}{l}\text { A: No } \\
\text { input of } \\
\text { fodder } \\
\text { (NIF) }\end{array}$ & Never buy fodder & $\begin{array}{l}\text { Pastoralists decide on herd size based on } \\
\text { the forage production on their pasture, and } \\
\text { never consider purchasing fodder. }\end{array}$ \\
\hline $\begin{array}{l}\text { B: Input } \\
\text { fodder } \\
\text { only in } \\
\text { disaster } \\
\text { years } \\
\text { (IFDY) }\end{array}$ & $\begin{array}{l}\text { Buy fodder only in } \\
\text { disaster years }\end{array}$ & $\begin{array}{l}\text { Pastoralists decide on herd size first based } \\
\text { on the available forage on their pasture, and } \\
\text { buy fodder only if drought or snow } \\
\text { disasters occur, under the precondition that } \\
\text { breeding ewes do not surpass the number at } \\
\text { the start of the year. }\end{array}$ \\
\hline $\begin{array}{l}\text { C: } \\
\text { Frequent } \\
\text { input of } \\
\text { fodder } \\
\text { (FIF) }\end{array}$ & $\begin{array}{l}\text { Buy fodder } \\
\text { whenever a forage } \\
\text { gap occurs, } \\
\text { regardless of year } \\
\text { type }\end{array}$ & $\begin{array}{l}\text { Pastoralists pursue maximization of the } \\
\text { number of breeding ewes for available } \\
\text { budget. Exogenous fodder is purchased } \\
\text { whenever the forage supply of the } \\
\text { household pasture could not meet the } \\
\text { demand. }\end{array}$ \\
\hline
\end{tabular}

Disasters here include both drought and snow disasters. A drought disaster year is defined as year in which the above ground biomass of pasture is $<70 \%$ of the historical average (Sun 1988). Because biomass is determined by precipitation in our model, we define a drought disaster year if the precipitation is $<70 \%$ of the historical average. A snow disaster year is defined as year with snow so heavy that the livestock are not able to reach the residuals on pasture for more than one month. For modeling, we randomly selected 14 of the 50 years as snow disaster years, as frequency of snow disaster in the study area was once every three to four years according to historical monitoring (Compiling Committee of Annals of Sonid Left Banner 2004).

\section{Outcome indicators to assess the impacts}

Based on the definition of resilience by Walker et al. (2006), we defined resilience in this study as the ability of pastoral households to endure climatic variability while maintaining the status of their livelihood and health of the rangeland ecosystem. The impacts on resilience were estimated in terms of household livelihood, livestock production, and rangeland ecosystem, with three outcome indicators of risk of bankruptcy, profit from pastoral production, and risk of overgrazing, respectively. The conceptualization and measurements of the three outcome indicators are described below.

Risk of bankruptcy: We used risk of bankruptcy as an indicator to reflect the impacts on household livelihood. Household bankruptcy occurs when livestock population declines to zero. The risk of bankruptcy was evaluated as frequency of bankruptcy over 1000 simulation runs. The risk was divided into five levels of very low, low, moderate, high, and very high, with the frequency of bankruptcy between $0-20 \%, 21-40 \%, 41-60 \%, 61-80 \%$ and $81-100 \%$, respectively.

Profit from livestock production: We used the accumulated profits from livestock production to measure the impacts on animal husbandry; it was calculated as the accumulated annual net cash income from livestock production and the increased value of stock herd population at the end of simulation.

Risk of overgrazing: We used grazing intensity in the warm season as a proxy for measuring the ecological impacts of grazing. Grazing intensity was defined as the ratio of biomass consumed to the total biomass produced on warm season pasture. Because the relationship between grazing intensity and rangeland degradation is complex, we used the ratio of $70 \%$ as the threshold for overgrazing. Once grazing intensity passed the threshold, it was identified as an overgrazing event. The frequency of overgrazing in the 50 years of simulation was used to indicate the ecological risk. The risk was divided into five levels of very low, low, moderate, high, and very high, when the frequency of overgrazing was between $0-20 \%, 21-40 \%, 41-60 \%, 61-80 \%$, and $81-100 \%$, respectively.

\section{Approaches to assess the impacts of fodder import and credit loans}

Impacts of fodder import: We assessed the impacts of fodder import by comparing the simulation outcomes for different fodder strategies. The model was run with the same initial conditions and parameters, but different fodder strategies. Fodder strategy was constant for a household during the process of each simulation. The impacts of fodder input were assessed by comparing the values of indicators for different fodder strategies. The outcomes without fodder input (the NIF strategy) were used as the reference, and then the outcomes of the IFDY and FIF strategies were compared to the reference. If any one of the three outcome impacts were worse than the reference, i.e., increased risk of bankruptcy, increased risk of rangeland degradation, and decreased accumulated profits, we concluded that fodder input reduced the resilience of the SES. In contrast, if any of the above three aspects improved over the reference, we concluded that fodder input enhanced the resilience. If the outcomes of any two indicators tended in opposite directions, the comprehensive impacts on the resilience were analyzed in terms of the degree of changes and the direct causes of those changes.

Impacts of credit loans: Because credit loans affect the decisions of livestock sale and fodder purchase, the impacts of those decisions could not be assessed without considering fodder strategies. Therefore, previous models were used with different amounts of available loans, starting from 0 (indicating no credit loan service available) to $5 \times 10^{4}$ Yuan. We used the outcomes with no credit loans (amount of available loan $=0$ ) as reference, and compared the outcomes of different credit loan scenarios to the corresponding reference for the same fodder strategy. The impacts on resilience were estimated using the same standard as we applied for fodder input. The results are presented for each fodder strategy, respectively.

\section{The agent-based model}

We elaborate our model following the ODD protocol (Grimm et al. 2006) as follows.

\section{Purpose}

The model was developed to analyze the impacts of fodder input and credit loans on the resilience of pastoral SES. It simulates the dynamics of herd size and structure, cash flow, and grazing intensity of a sheep-raising household with different fodder strategies and different levels of credit loans. 


\section{State variables and scale}

The state variables of the model (Table 2) consisted of four categories: (1) annual total precipitation of the t-th year $\mathrm{P}(\mathrm{t})$; (2) herd variables, which describe the size and structure of the herd. Sheep herds were classified into eight types according to sex and age, including the male lamb (type 1), female lamb (type 2), 1year-old ewe (type 3), 2-year-old ewe (type 4), 3-year-old ewe (type 5), 4-year-old ewe (type 6), 5-year-old ewe (type 7) and 6-year-old ewe (old sheep, type 8). The sheep number in each sex-age type was recorded as $\mathrm{N}_{\mathrm{i}}(\mathrm{t})(\mathrm{i}=1 \ldots 8)$. In addition, variables related to the whole herd were also recorded, including herd size $N_{h}(t)$, total number of sheep sold $\mathrm{Q}_{\mathrm{s}}(\mathrm{t})$, and the number of old (6-year-old) and sick sheep $\mathrm{Q}_{1}(\mathrm{t})$; (3) fodder variables, including the amount of usable forage on pastures for warm season $\mathrm{F}_{\mathrm{p}_{-} \mathrm{w}}(\mathrm{t})$, cold season $\mathrm{F}_{\text {pasture }}(\mathrm{t})$, and bought fodder $\mathrm{F}_{\text {input }}(\mathrm{t})$; (4) cash flow variables, including costs of production $\mathrm{C}_{\text {pro }}(\mathrm{t})$, income $\operatorname{In}(\mathrm{t})$, amount of loans $\mathrm{L}(\mathrm{t})$, and savings $\mathrm{S}(\mathrm{t})$.

Table 2. Set of state variables in the model.

\begin{tabular}{llcc}
\hline \hline Entity & State variables & Symbol & Unit \\
\hline $\begin{array}{l}\text { Precipita- } \\
\text { tion }\end{array}$ & Annual precipitation & $\mathrm{P}(\mathrm{t})$ & {$[\mathrm{mm}]$} \\
Livestock & Herd size & $\mathrm{N}_{\mathrm{h}}(\mathrm{t})$ & {$[$ count $]$} \\
& Number of sheep in each age-sex & $\mathrm{N}_{\mathrm{i}}(\mathrm{t})$ & {$[$ count $]$} \\
& category (male lamb, female lamb, 1- & $(\mathrm{i}=1 \ldots 8)$ & \\
& yr-old ewe ... 6-yr-old ewe) & & \\
& Number of old and sick sheep & $\mathrm{Q}_{1}(\mathrm{t})$ & {$[$ count $]$} \\
& Total number of sheep for sale & $\mathrm{Q}_{\mathrm{s}}(\mathrm{t})$ & {$[\mathrm{count}]$} \\
Fodder & Biomass & $\mathrm{B}(\mathrm{t})$ & {$[\mathrm{kg} / \mathrm{ha}]$} \\
& Usable forage on pastures for warm & $\mathrm{F}_{\mathrm{p}_{-} \mathrm{w}}(\mathrm{t})$ & {$[\mathrm{kg}]$} \\
& season & $\mathrm{F}_{\mathrm{p} \_\mathrm{c}}(\mathrm{t})$ & {$[\mathrm{kg}]$} \\
& Usable forage on pastures for cold & $\mathrm{F}$ & \\
& season & $\mathrm{F}_{\text {input }}(\mathrm{t})$ & {$[\mathrm{kg}]$} \\
& Bought fodder & $\mathrm{C}_{\mathrm{pro}}(\mathrm{t})$ & {$[\mathrm{Yuan}]$} \\
Cash flow & Costs of production & $\mathrm{In}(\mathrm{t})$ & {$[\mathrm{Yuan}]$} \\
& Income & $\mathrm{L}(\mathrm{t})$ & {$[\mathrm{Yuan}]$} \\
& Amount of loan & $\mathrm{S}(\mathrm{t})$ & {$[\mathrm{Yuan}]$} \\
\hline
\end{tabular}

This model was constructed at a household scale without interactions with other agents. Because households in the study area use their contracted pastures only, and move to rented pastures only occasionally, interactions with other households about pastoral production are rare and thus ignored. The time horizon of simulation was 50 years and the time step was one year.

\section{Process overview and scheduling}

Key processes in pastoral SES in the study area were sorted into 6 procedures in the model, according to their sequence within one time step, as shown in Figure 2.

Process 1: Precipitation and snow disasters. Precipitation $\mathrm{P}(\mathrm{t})$ for each year was randomly generated from a normal distribution of historical precipitation in the study area. If the annual precipitation was $<70 \%$ of long-term average, it was recorded as drought disaster (Sun 1988). Snow disaster years were randomly selected based on the frequency of snow disasters in the study area.

Process 2: Usable forage on WSP. Usable forage is the forage that could be grazed on pasture. In arid desert-steppes of Inner Mongolia, rainfall is the primary determinant of vegetation biomass (Bai et al. 2008). The biomass $\mathrm{B}(\mathrm{t})$ of a pasture was calculated in this study by multiplying precipitation $\mathrm{P}(\mathrm{t})$ and rain use efficiency (RUE), which is the ratio of above-ground net primary production to precipitation (Le Houerou 1984). The usable forage on WSP was the product of biomass $\mathrm{B}(\mathrm{t})$, area of WSP $A_{w}$, and utilization rate $\eta$, which is an empirical value determined by the characteristics of the pastures, such as vegetation type and landforms.

Fig. 2. Key processes in a rangeland social-ecological system in the study area. Notes: The figure shows how pasture forage, herd size and structure, and cash flow are interlinked and changed in one production cycle. The variables in grey boxes are the key factors of pastoralists' stocking decisions. The starting point of the arrow is the driving factor and the end is the affected factor. The lines with two-way arrows indicate that the two variables are interactive. WS - warm season, CW - cold season, WSP - warm-season-pasture, CSP - cold-seasonpasture.

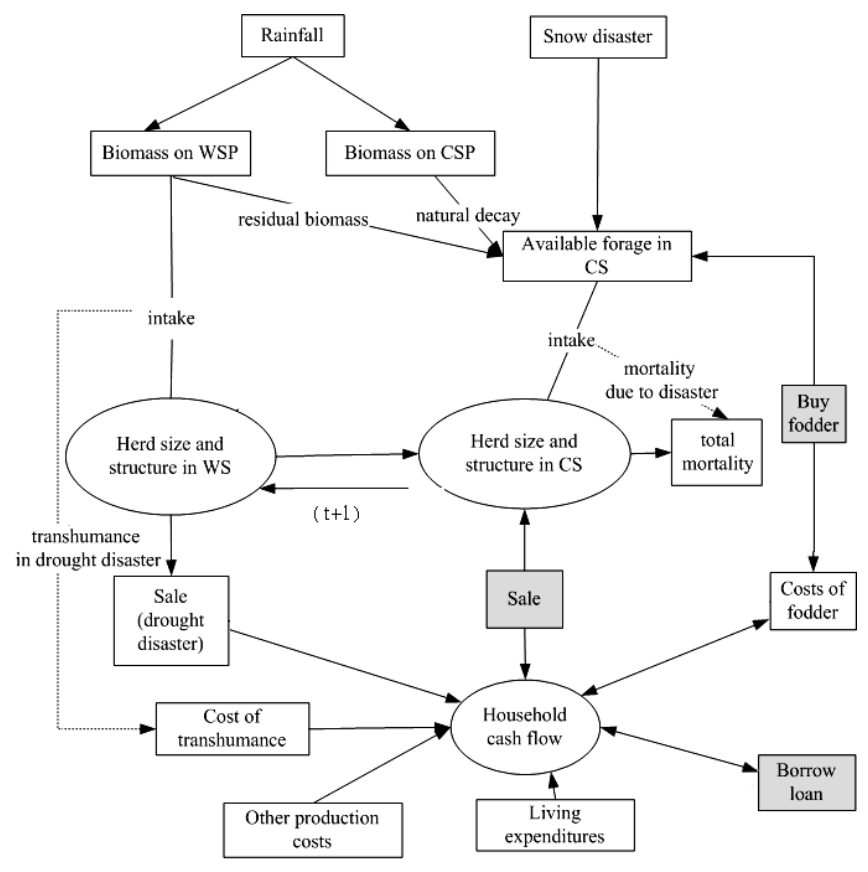

Process 3: Herd and cash flow dynamics in warm season. Herd dynamics depend on the availability of usable forage in the warm season. We assumed a constant birth-and-survival rate $\alpha$ among different age type of ewes $\left(\mathrm{N}_{3}\right.$ to $\left.\mathrm{N}_{7}\right)$ and 1:1 sex ratio of newborn lambs. Forage demand was determined by the number of sheep $\mathrm{N}_{\mathrm{h}}$, daily intake $\varepsilon$ and days of warm season $\mathrm{D}_{\mathrm{w}}$. If usable forage was insufficient on WSP, the herd could move and graze on rented pastures, if the household could afford the rent, which induced transhumance costs. If cash was not sufficient for a rental of pasture, a certain percentage of sheep were sold.

Process 4: Usable forage on CSP. The usable forage on CSP was determined by the biomass $\mathrm{B}(\mathrm{t})$, area of CSP $\mathrm{A}_{\mathrm{c}}$, utilization rate $\eta$, and reserved rate $\gamma$ which is the ratio of forage residue in cold season to the biomass in peak growth season and it represents the loss of biomass due to wind blow and natural decay. Forage 
residue on WCP could also be grazed during cold season, and the amount of forage was discounted by the reserved rate $\gamma$.

Process 5: Stocking decisions, and herd and cash flow dynamics at the end of warm season. In this part, the agent made decisions on livestock sale, fodder import, and credit loans based on the rules of their fodder strategies, with the aim of maximizing the number of breeding ewes under the constraints of balancing income and costs, as well as forage supply and demands. The process and formulas of decision making for each fodder strategy are shown in Figure 3.

Similar to earlier observations (Ellis and Swift 1988, Dercon and Krishnan 1996), the pastoralists in our study area traditionally considered livestock to be wealth savings, and had no habit of keeping cash. Currently, once they obtain cash, they usually prefer to invest in some assets (such as a car or housing) or infrastructure, rather than deposit in banks. Such investment expenditures varied greatly across years, and it was very difficult to learn of exact amounts via household interviews. Therefore, we simplified this by setting a ceiling ( $S^{\prime}$ ) on the amount of annual savings $S$; if the amount of net income minus living expenditures exceeds $S$ ', then $\mathrm{S}$ equals $\mathrm{S}$, otherwise, $\mathrm{S}$ equals net income minus living expenditures.

Process 6: Herd and cash flow dynamics in cold season. Snow disasters affect pastoral production in cold season. If no snow disaster occurred, herd size and structure was updated by the reduction of the number of deaths from each age-sex category, with a constant mortality $\beta$, which was assumed to be uniform for each age-sex category. If snow disaster occurred, forage availability was calculated by multiplying usable forage on pasture with a deficit factor $\mathrm{k}$, which was determined by the severity of snow disaster. If the agent adopts fodder strategy of "purchase when fodder gaps exist" (FIF strategy) or "import fodder only in disaster years" (IFDY strategy), he buys fodder based on forage demands, savings, and available credit loan. After that, if forage gap continued, then additional mortality $x$ occurred, which was assumed to be the proportion of fodder gap to total fodder demands. At the end of the cold season, the state variables related to herd size, cash flow, and forage dynamics, as well as the agesex category of herd were updated for the next running year.

\section{Design concepts}

Adaptation: Stocking decision was the sole adaptive trait in the model. Households made stocking decisions annually, based on their current herd size and structure, forage availability, and cash flow, by evaluating the demand and supply of forage and cash, and deciding on the type and number of sheep to sell to optimize production potential.

Interaction: There was only one agent in the model, therefore no interactions were included.

Observations: The key outputs from the model included herd size and structure, yearly grazing intensity on warm season pastures, and annual income from sheep sale.

Prediction: No prediction was modeled.

Sensing: The agents can sense forage demand and supply in their ranch, sheep price, and their cash flow. The agents who adopt the Input Fodder Only in Disaster Years strategy can sense when disaster years occur.
Fig. 3. Flow chart of the processes of the agents' stocking decision. With input of information, the agents with different fodder strategies decide the amount of livestock to sell, forage to buy, and credit loan to borrow according to the decision process and the formulas. NIF - no import of forage, FIDY import of forage only in disaster years, FIF - import of forage whenever forage gaps exist, Finput - amount of purchased fodder, Os - total number of sheep for sale, L - amount of credit loan to borrow, Fpasure - usable forage on the pasture in cold season., Nh - total number of sheep, Q1 - number of sheep for sale at first stage, is the sum of the number of old, sick, and male lambs. $\varepsilon$ - daily forage intake per sheep, Dc - total days in cold season, It - target income, It = total production costs before fodder purchase + living expenditures + savings in previous year + loan (if exists) in the previous year - available loan, Ps_au - price of sheep in autumn, Pf_au - price of fodder in autumn, $\mathrm{Ne}$ - number of ewes at the beginning of the year. Cpro - production costs, Cdom - family expenditures, L (t-1) loans in the previous year, $\mathrm{S}(\mathrm{t}-1)$ - savings in the previous year. Detailed explanations of the formulas are provided in Appendix 1.

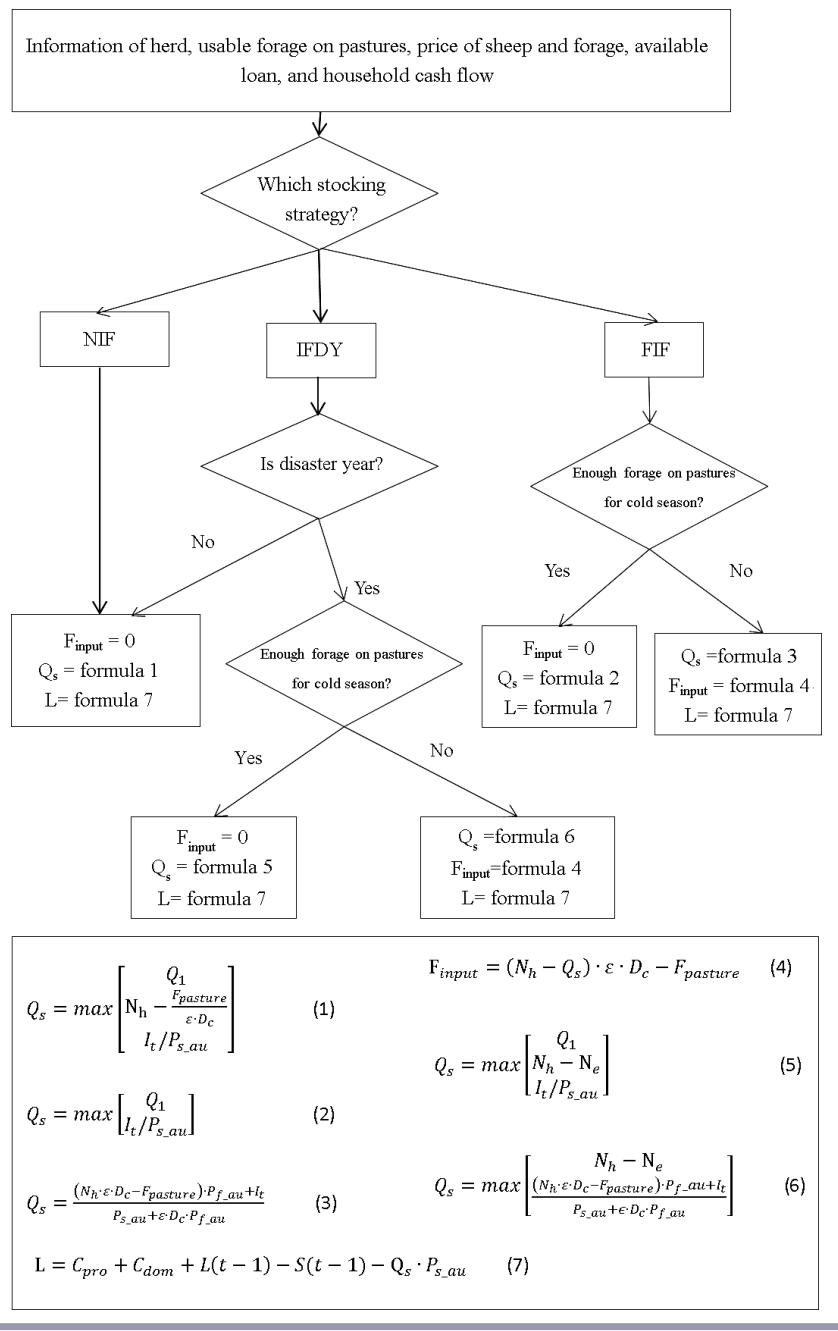


Table 3. List of parameters, the default parameter set, and references.

\begin{tabular}{|c|c|c|c|c|}
\hline Parameter & $\begin{array}{l}\text { Abbreviat- } \\
\text { ion }\end{array}$ & Unit & Values & Sources \\
\hline \multicolumn{5}{|l|}{ Climatic parameters } \\
\hline Days of cold-season & $\mathrm{D}_{\mathrm{c}}$ & [Day] & 205 & $\begin{array}{l}\text { Bureau of Standard Measurement of Inner Mongolia } \\
1990\end{array}$ \\
\hline Days of warm-season & $\mathrm{D}_{\mathrm{w}}$ & [Day $]$ & 160 & $\begin{array}{l}\text { Bureau of Standard Measurement of Inner Mongolia } \\
1990\end{array}$ \\
\hline Mean annual precipitation & $\mathrm{R}$ & {$[\mathrm{mm}]$} & 191 & Meteorological Bureau of Sonid Left Banner \\
\hline $\begin{array}{l}\text { Standard deviation of annual } \\
\text { precipitation }\end{array}$ & $\sigma$ & {$[\mathrm{mm}]$} & 55.4 & Meteorological Bureau of Sonid Left Banner \\
\hline Frequency of snow disasters & $\mathrm{F}_{\mathrm{sd}}$ & [times per year] & 0.28 & $\begin{array}{l}\text { Compiling Committee of Annals of Sonid Left Banner } \\
2004\end{array}$ \\
\hline $\begin{array}{l}\text { Ratio of precipitation threshold to } \\
\text { mean annual precipitation }\end{array}$ & Bdd & $\begin{array}{l}\text { Dimensionless } \\
\quad \text { (rate) }\end{array}$ & 0.7 & Sun 1988 \\
\hline \multicolumn{5}{|l|}{ Ecological parameters } \\
\hline Use-efficiency of rainfall & RUE & {$\left[\mathrm{g} / \mathrm{m}^{2} \cdot \mathrm{mm}\right]$} & 0.24 & Bai et al. 2008 \\
\hline Utilization rate of forage in pasture & $\eta$ & $\begin{array}{l}\text { Dimensionless } \\
\quad \text { (rate) }\end{array}$ & 0.8 & $\begin{array}{l}\text { Bureau of Standard Measurement of Inner Mongolia } \\
1990\end{array}$ \\
\hline Reserve rate of forage in pasture & $\gamma$ & $\begin{array}{l}\text { Dimensionless } \\
\quad \text { (rate) }\end{array}$ & 0.603 & $\begin{array}{l}\text { Compiling Committee of Annals of Sonid Left Banner } \\
2004\end{array}$ \\
\hline $\begin{array}{l}\text { Reduction ratio of usable forage caused } \\
\text { by snow disasters }\end{array}$ & $\mathrm{k}$ & $\begin{array}{l}\text { Dimensionless } \\
\text { (rate) }\end{array}$ & $0.146-0.292$ & Estimation based on our case study survey in 2007 \\
\hline \multicolumn{5}{|l|}{ Livestock related parameters } \\
\hline Fodder/forage intake per day per sheep & $\varepsilon$ & {$[\mathrm{kg}]$} & 2 & $\begin{array}{l}\text { Bureau of Standard Measurement of Inner Mongolia } \\
1990\end{array}$ \\
\hline Birth-survival rate of lamb & $\alpha$ & $\begin{array}{l}\text { Dimensionless } \\
\quad \text { (rate) }\end{array}$ & 0.917 & $\begin{array}{l}\text { Collected from Statistics Bureau of Sonid Left Banner } \\
\text { in } 2006\end{array}$ \\
\hline Mortality of sheep in normal years & $\beta$ & $\begin{array}{l}\text { Dimensionless } \\
\text { (rate) }\end{array}$ & 0.003 & $\begin{array}{l}\text { Collected from Statistics Bureau of Sonid Left Banner } \\
\text { in } 2006\end{array}$ \\
\hline Sickness rate of sheep in normal years & $\omega$ & $\begin{array}{l}\text { Dimensionless } \\
\text { (rate) }\end{array}$ & 0.05 & Estimation based on our fieldwork during 2006 to 2011 \\
\hline Area of cold-season-pasture & $\mathrm{A}_{\mathrm{c}}$ & [ha] & 461 & Fieldwork in 2006 \\
\hline Area of warm-season-pasture & $\mathrm{A}_{\mathrm{w}}^{\mathrm{c}}$ & [ha] & 426 & Fieldwork in 2006 \\
\hline $\begin{array}{l}\text { Number of sheep in the initial year } \\
\text { Economic parameters }\end{array}$ & $\mathrm{N}_{\text {intial }}$ & [sheep] & 618 & Fieldwork in 2006 \\
\hline Price of sheep in autumn & $\mathrm{P}_{\mathrm{s}}$ & [Yuan per sheep] & $\begin{array}{l}310 \text { (ewe), } \\
200 \text { (lamb) }\end{array}$ & Fieldwork in 2006 \\
\hline Price of sheep in summer & $\mathrm{P}_{\mathrm{ss}}$ & [Yuan per sheep] & $\begin{array}{l}165(\text { ewe }) \\
100(\text { lamb })\end{array}$ & Fieldwork in 2006 \\
\hline $\begin{array}{l}\text { Cost of moving herd in warm season } \\
\text { when drought occurred (converted into } \\
\text { forage consumed) }\end{array}$ & $\mathrm{C}_{\text {tran }}$ & $\begin{array}{l}\text { [Yuan per } \mathrm{kg} \text { of } \\
\text { forage] }\end{array}$ & $\begin{array}{l}0.14-0.28 \text { [negatively } \\
\text { varying linearly with } \\
\text { annual precipitation] }\end{array}$ & Estimation based on our fieldwork in 2006 \\
\hline Price of forage in autumn & $\mathrm{P}_{\mathrm{f}_{-} \mathrm{au}}$ & [Yuan per kg] & $\begin{array}{l}0.45-0.90 \text { [negatively } \\
\text { varying linearly with } \\
\text { annual precipitation] }\end{array}$ & Estimation based on our fieldwork during 2006 to 2011 \\
\hline $\begin{array}{l}\text { Price of forage when snow disasters } \\
\text { occurred }\end{array}$ & $P_{f_{-} s}$ & [Yuan per kg] & $\begin{array}{l}\text { [twice of the price in } \\
\text { the autumn] }\end{array}$ & Estimation based on our fieldwork during 2006 to 2011 \\
\hline Cost of labor & $\mathrm{C}_{1}$ & $\begin{array}{l}\text { [Yuan per shepherd } \\
\text { per year] }\end{array}$ & $\begin{array}{c}1000 \text { [a shepherd for } \\
1300 \text { sheep] }\end{array}$ & Estimation based on our fieldwork in 2006 \\
\hline $\begin{array}{l}\text { Cost of energy (electricity and } \\
\text { gasoline) }\end{array}$ & $\mathrm{C}_{\mathrm{e}}$ & $\begin{array}{c}\text { [Yuan per sheep per } \\
\text { year] }\end{array}$ & 6.672 & Estimation based on our fieldwork in 2006 \\
\hline Cost of veterinary treatments & $\mathrm{C}_{\mathrm{v}}$ & $\begin{array}{c}\text { [Yuan per sheep per } \\
\text { year] }\end{array}$ & 2.206 & Estimation based on our fieldwork in 2006 \\
\hline Cost of facilities maintenance per year & $\mathrm{C}_{\mathrm{m}}$ & [Yuan per year] & 1000 & Estimation based on our fieldwork in 2006 \\
\hline Family expenditures & $\mathrm{C}_{\mathrm{dom}}^{\mathrm{m}}$ & [Yuan per year] & 16,875 & Estimation based on our fieldwork in 2006 \\
\hline Upper limit on savings & $\stackrel{\text { dom }}{S}^{\prime}$ & [Yuan] & 20,000 & \\
\hline
\end{tabular}

\section{Details}

Initialization: The initial herd size was set at 618 sheep per household; that is the average number of sheep per household in our survey in the study area, as described below and in Table 3. The sheep number in each sex-age type was set to [140, 140, 40, $56,50,60,71,60$ ] for [male lamb (type 1), female lamb (type 2), 1-year-old ewe (type 3), 2-year-old ewe (type 4), 3-year-old ewe (type 5), 4-year-old ewe (type 6), 5-year-old ewe (type 7), and 6year-old ewe (type 8)], respectively. The number of lambs was estimated by the ratio of lamb to ewe based on birth-and-survival rate. The number of ewes in each group was randomly assigned to between 40 and 80 . The initial savings of households was set at 20,000 Yuan, which is the limit for savings in the model, and the initial credit loan was set to zero. 
Parameter assignments: Values of climatic and ecological parameters (Table 3) were collected during our field surveys, from government agencies, related documents, and publications. Data for economic parameters were obtained from in-depth household interviews in B village $\left(\mathrm{N} 44^{\circ} 01^{\prime}-17^{\prime}, \mathrm{E} 113^{\circ} 23^{\prime}-37^{\prime}\right)$ of Sonid Left Banner in 2006. With the assistance of a Mongolian interpreter, 28 households (accounting for $37 \%$ of total pastoral households in $\mathrm{B}$ village) were selected using the stratification sampling method, and semistructured interviews were conducted with the household heads to collect detailed information on herd structure, production costs, income and living expenditures, and other parameters.

\section{Monte-Carlo simulation}

Because climate is highly variable and uncertain in arid rangeland (Reynolds et al. 2007), it is difficult to draw any reliable conclusions from the outputs of a single simulation because the outputs represent only one realization of a stochastic process. We used Monte-Carlo simulations (MCS) to find the most possible results under the stochastic climate. MCS is based on repetition of numerous model iterations, each of them using a set of parameters that is randomly picked from the underlying probability distributions of the most influential parameters (Schade and Wiesenthal 2011). Through the process, a mimic realistic distribution of output values is generated, and subsequently analyzed using standard statistical methods to generate the best estimate of the required measurements, corresponding to the set of input values (Basil and Jamieson 1999). MCS has been applied to studies on pastoral strategies (Christensen et al. 2003, Hahn et al. 2005, Müller et al. 2007, DíazSolís et al. 2009) to address the variability in precipitation.

In this study, climate parameters (precipitation, snow disaster year, and degree of severity over a 50-year period) are randomly generated based on the distribution pattern of the historical records in the study area. For each set of climate parameters, the duration of pastoral production, frequency of overgrazing years, and accumulated revenues are calculated for three fodder strategies (Table 3), respectively, after 50 years of simulation and over 1000 model reiterations.

\section{Scenarios of livestock price}

Because the market price of livestock products and daily living expenses affect household cash flow, and further affect pastoral production, we set six scenarios for sheep price. We applied market prices for the year 2006, when fieldwork was conducted, as the baseline scenario (200 Yuan per lamb, and 310 Yuan per adult sheep). The prices in other scenarios were set to $1 / 2,1.5,2,2.5$, and 3 times of the baseline, respectively. The market price of sheep has increased since the fieldwork, and in recent years was around 2.5 times the baseline.

The model was built and ran in Matlab software (Version 2012b). All codes of the model have been shared on CoMSES website ( $\mathrm{Li}$ 2019). We used SPSS 16.0 software to generate descriptive statistics for all outcomes generated from the running of the model. We used a paired t-test to compare the outcomes for normally distributed data, and two-paired Wilcoxon signed ranks test for not normally distributed data. The figures were plotted with R Studio software (Version 1.1.442).

\section{RESULTS}

\section{The impacts of fodder import without loan credits}

Results of the baseline scenario

The outputs of the three fodder strategies for the baseline scenario are shown in Figure 4. In this scenario, the annual market prices of livestock, forage, and living costs were set as real prices in year 2006.

Fig. 4. Outcomes of different fodder strategies with the baseline scenario. NIF - no import of fodder, IFDY - import fodder only in disaster years, FIF - frequent import of fodder.
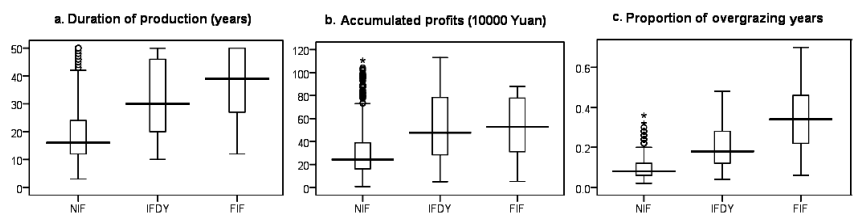

The risk of bankruptcy existed for all of the three fodder strategies used in this study. The simulated household bankrupted at 98.0, 77.8 , and $65.6 \%$ of simulations for NIF (no input of fodder), IFDY (input fodder in disaster years), and FIF (frequent input of fodder) strategies, respectively. The duration of time that the production system could sustain itself before bankruptcy was shortest for the NIF strategy (average 19.1 years), followed by the IFDY strategy (32.3 years), and was longest for the FIF strategy (37.2 years).

Accumulated profits of livestock production were higher with the IFDY strategy $\left(5.34 \times 10^{5}\right.$ Yuan on average $)$ than with the FIF strategy $\left(5.23 \times 10^{5}\right.$ Yuan, $\left.p<0.001\right)$, and both were significantly higher than with the NIF strategy $\left(2.99 \times 10^{5}\right.$ Yuan, $\left.p<0.001\right)$.

The risk of overgrazing was highest with the FIF strategy, followed by IFDY and NIF strategy. The average proportion of overgrazing years to the total years of simulation (50) was $9.3 \%$ with NIF, 20.3\% with IFDY, and $34.6 \%$ with the FIF strategy.

Results of scenarios with different livestock prices

The patterns of outcomes of three fodder strategies were similar with different livestock price scenarios (Fig. 5). The pastoral household bankrupted within 10 years when livestock price was set at $1 / 2$ of the baseline, no matter which strategy was adopted. When livestock prices were higher than the baseline scenario, the production lasted longer. When livestock price reached 1.5 times that of the baseline, the production could last until the end of simulation (50 years) when fodder was imported, either in disaster years (the IFDY strategy) or in both, disaster and climatically normal years (the FIF strategy). The risk of bankruptcy existed in all price scenarios, with no import of fodder. The household bankrupted in $4.5 \%$ of simulations even when the price of livestock reached 3 times that of the baseline.

Households with the IFDY strategy gained higher accumulated livestock production profits than those with the other two strategies for all price levels (df. $=999, \mathrm{p}<0.001$; Fig. 5b). The relative advantage of the other two strategies depended on price level. When livestock prices dropped below a certain threshold (between baseline to 1.5 times that in this study), the household 
that did not import fodder (the NIF strategy) gained lower ( $p<$ 0.001 ) profits than those that frequently imported fodder (the FIF strategy). However, when the price was higher than the threshold, the opposite outcome was generated $(p<0.001)$.

Fig. 5. The impacts of fodder input on (a) household livelihood, (b) livestock production, and (c) ecosystem health for different livestock price scenarios. Accumulated profits (b) were adjusted based on sheep price level to represent the actual impacts of pastoral production on the increase in value. NIF no import of fodder, IFDY - import fodder only in disaster years, FIF - frequent import of fodder.

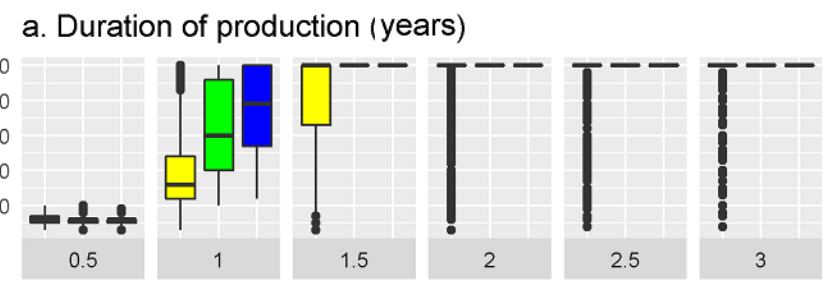

Price of livestock (\# of times the baseline scenario)

\section{b. Accumulated profits (10000 Yuan)}

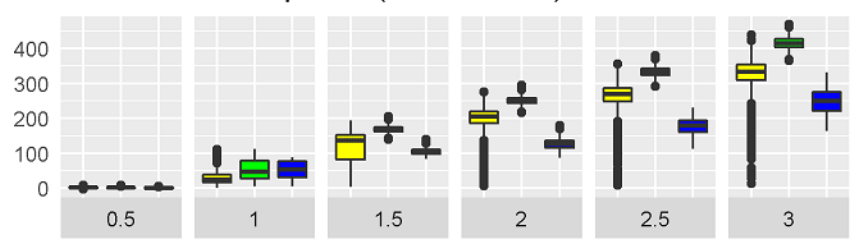

Price of livestock (\# of times the baseline scenario)
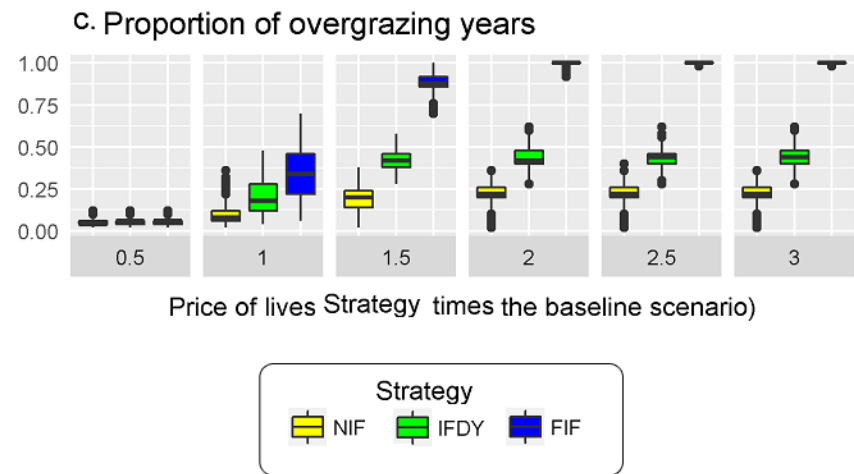

The ranking of ecological risk for the three strategies with different livestock prices was similar to that for the baseline price scenario, i.e., NIF $<$ IFDY $<$ FIF (Fig. 5c). Overall, when no fodder was imported (the NIF strategy) or when it imported only in disaster years (the IFDY strategy), ecological risks did not vary with livestock price once a certain price threshold was surpassed. However, with the FIF strategy, the ecological risks approached $100 \%$ with an increase in livestock price. The average proportion of overgrazing years with IFDY did not exceed $45 \%$ for all price scenarios, but reached $99 \%$ with FIF when livestock price reached 2 times that of baseline.
Because most of the simulations ended before the simulation period of 50 years when livestock price was at the baseline scenario, we present an example of temporal changes in herd size, production costs, and annual profits for a simulation when livestock price was 2 times that of the baseline (Fig. 6). It clearly shows that rainfall and snow disasters strongly shape the dynamics of pastoral production. Frequent import of fodder helps to maintain a larger herd than the other two fodder strategies, but it also results in much higher production costs and fluctuating annual profits.

Impacts of fodder imports on the resilience of pastoral SES The impacts on livelihood, production profits, and ecosystem indicated that the conditional importation of fodder (import only in disaster years, the IFDY strategy) could make the SES more resilient to climate uncertainty by reducing the risk of bankruptcy and increasing production profits (Table 4). Although the risk of overgrazing increased as well, it was moderate because grazing intensity over the threshold occurred on average in 22.5 out of 50 years $(45 \%)$.

Table 4. Summary of the impacts of fodder strategies at different levels of fodder input.

\begin{tabular}{|c|c|c|c|c|}
\hline $\begin{array}{l}\text { Sheep price } \\
\text { scenario }\end{array}$ & Impacts & $\begin{array}{l}\text { No fodder } \\
\text { input }\end{array}$ & $\begin{array}{l}\text { Input fodder } \\
\text { in disaster } \\
\text { years }\end{array}$ & $\begin{array}{l}\text { Frequent } \\
\text { input of } \\
\text { fodder }\end{array}$ \\
\hline $\begin{array}{l}\text { Low } \\
\text { (baseline) }\end{array}$ & $\begin{array}{l}\text { Risk of bankruptcy } \\
\text { Profits } \\
\text { Risk of rangeland } \\
\text { degradation }\end{array}$ & $\begin{array}{l}\text { Very high } \\
\text { Low } \\
\text { Very low }\end{array}$ & $\begin{array}{l}\text { High } \\
\text { Moderate } \\
\text { Very low }\end{array}$ & $\begin{array}{c}\text { High } \\
\text { Moderate } \\
\text { Low }\end{array}$ \\
\hline $\begin{array}{l}\text { High } \\
\text { ( } 2 \text { times } \\
\text { that of } \\
\text { baseline) }\end{array}$ & $\begin{array}{l}\text { Risk of bankruptcy } \\
\text { Profits } \\
\text { Risk of rangeland } \\
\text { degradation } \\
\text { Resilience }\end{array}$ & $\begin{array}{c}\text { Very low } \\
\text { High } \\
\text { Low }\end{array}$ & $\begin{array}{l}\text { None } \\
\text { Very high } \\
\text { Moderate } \\
\text { Increase }\end{array}$ & $\begin{array}{l}\text { None } \\
\text { Moderate } \\
\text { Very high } \\
\text { Decrease }\end{array}$ \\
\hline
\end{tabular}

Frequent importation of fodder (the FIF strategy) would make the SES more resilient only when livestock prices were low (equal to the baseline livestock price in this study), given that it reduced the risk of bankruptcy and increased the profits with moderate ecological risks (the average frequency of overgrazing was $34.6 \%$ ). However, when livestock prices increased, frequent importation of fodder increased vulnerability of SES over other strategies. Although the risk of bankruptcy was reduced as well, the risk of overgrazing approached $100 \%$, and the production profits decreased compared to the NIF strategy. A brief summary of the results is shown in Table 4.

\section{Impacts of credit loans for different fodder strategies}

Our results with different price scenarios showed that the impacts of credit loans on the pastoral system were strongly affected by livestock price. We present the results with baseline livestock price scenario (Fig. 7) and twice that of baseline scenario (Fig. 8).

\section{Results of the baseline livestock price scenario}

For the baseline price scenario with no fodder imported (the NIF strategy), the risk of bankruptcy for a household with credit loans was significantly lower $(p<0.001)$ than for one without credit loan, and the production profits and the risk of overgrazing were both significantly higher ( $p<0.001$; yellow boxplot, Fig. 7$)$. The 
Fig. 6. A simulation example of herd size, production costs, and annual profit dynamics over time in one simulation when livestock price was two times that of baseline scenario. NIF - no import of fodder, IFDY - import of fodder only in disaster years, FIF frequent import of fodder.

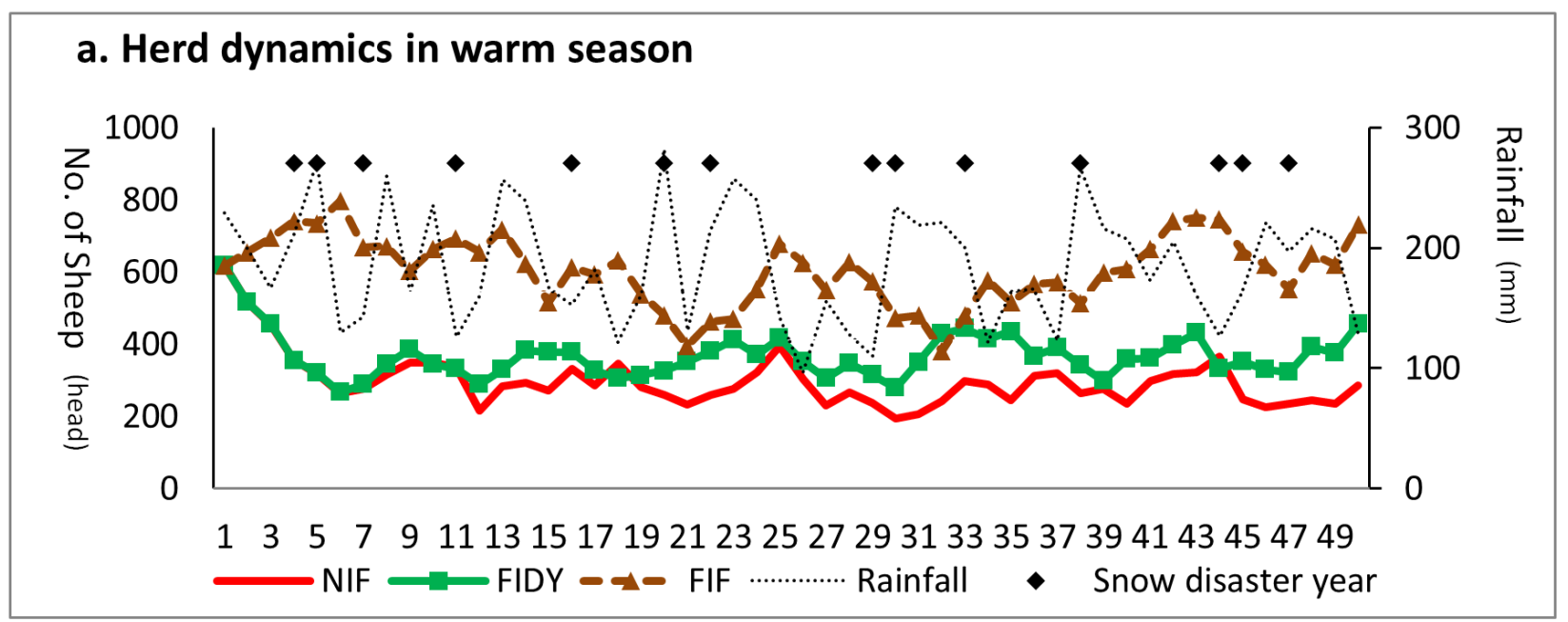

\section{b. Dynamics of production costs}

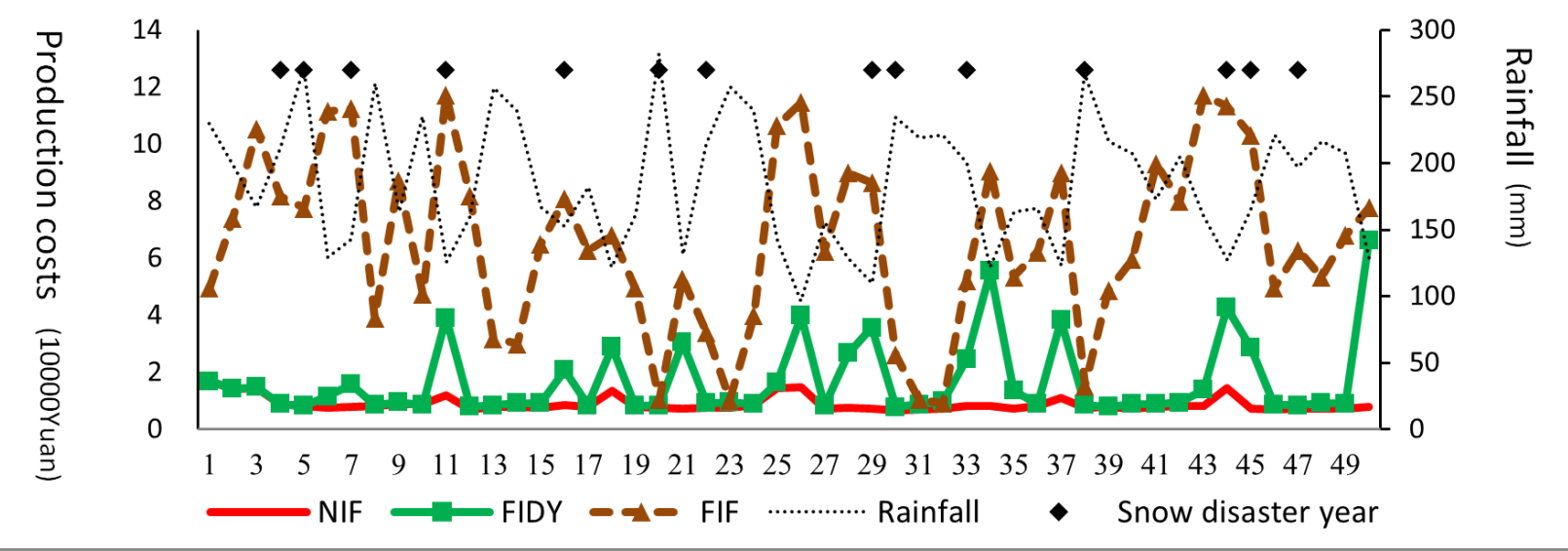

\section{c. Dynamics of annual profits}

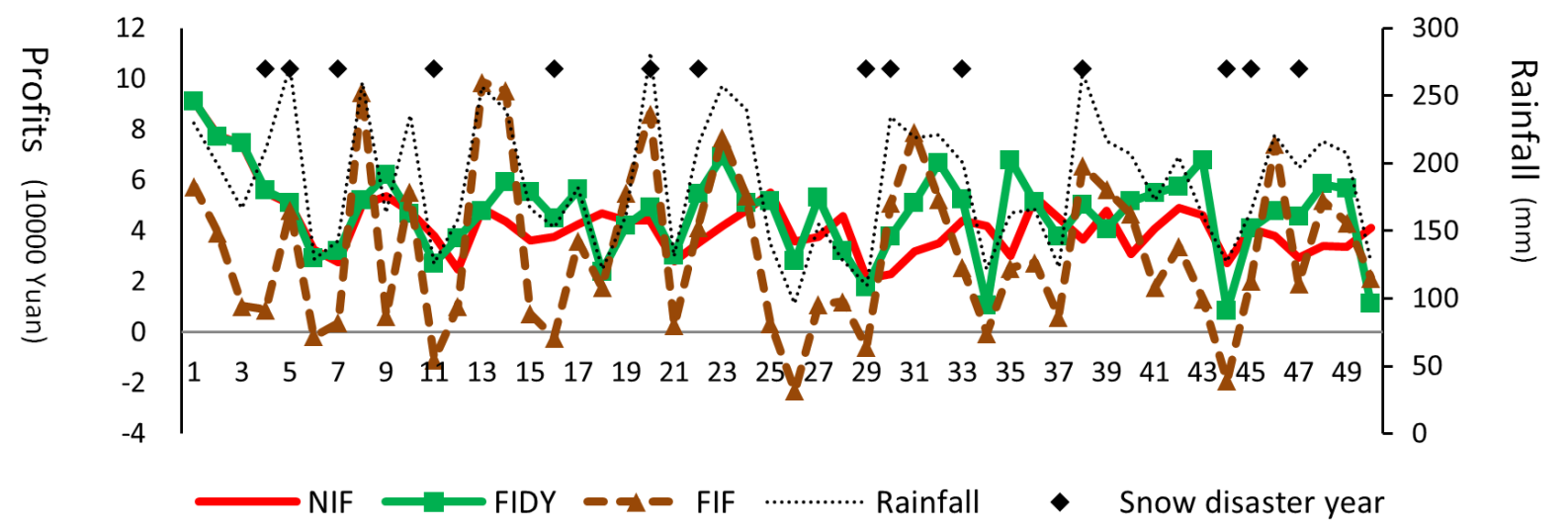


effects were increasingly obvious when the amount of available loans increased. When the amount of available loans increased from 0 to $5 \times 10^{4}$ Yuan, the risk of bankruptcy decreased from 98.0 to $90.8 \%$ and the average duration of production increased from 19.0 years to 27.4 years; further, the profits of production increased from $2.98 \times 10^{5}$ to $3.99 \times 10^{5}$ Yuan; and the average frequency of overgrazing increased from 9.3 to $13.2 \%$.

Fig. 7. Impacts of loans on (a) household livelihood, (b) livestock production, and (c) ecosystem health with different forage import strategies for the baseline scenario. NIF - no import of fodder, IFDY - import of fodder only in disaster years, FIF - frequent import of fodder.
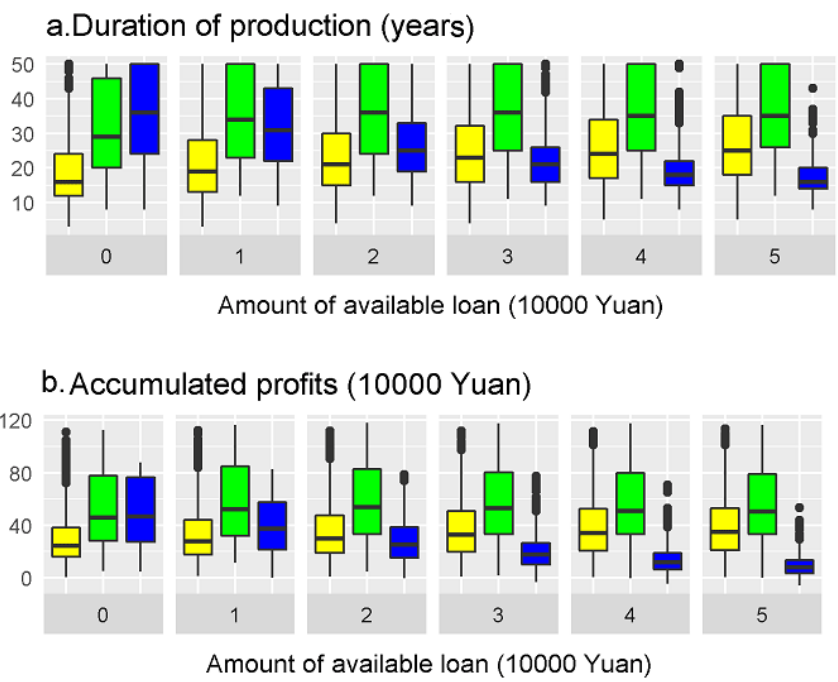

\section{c. Proportion of overgrazing years}
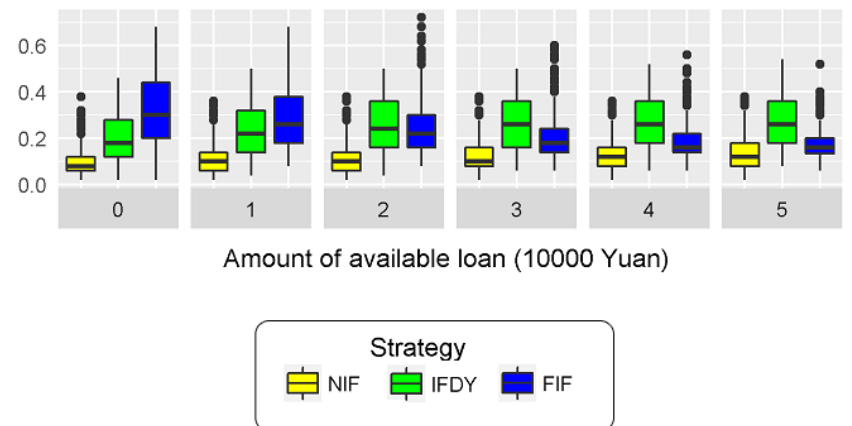

With the baseline price scenario and the IFDY strategy (fodder input in disaster years), risk of bankruptcy for households with credit loans was significantly lower $(p<0.001)$ than for those without credit loans (green boxplot, Fig. 7). Production profits and the risk of overgrazing were both significantly higher $(p<$ $0.001)$. When the amount of available loan increased from zero to $5 \times 10^{4}$ Yuan, the risk of bankruptcy decreased from 77.8 to $73.1 \%$, and the average duration of production increased from 32.0 to 35.9 years (Fig. 6a). Production profits changed as a reverse U-shape curve with increasing amount of available loans (Fig. 6b). Average profits were highest $\left(5.70 \times 10^{5}\right.$ Yuan) when the amount of available loans was $2 \times 10^{4}$ Yuan. The average proportion of overgrazing years increased from 20.2 to $27.8 \%$ when the amount of available loan increased from zero to $5 \times 10^{4}$ Yuan (Fig. 6c).

Fig. 8. Impacts of loans on (a) household livelihood, (b) livestock production, and (c) ecosystem health with different forage import strategies when the price of livestock was twice that of baseline scenario. NIF - no import of fodder, IFDY import of fodder only in disaster years, FIF - frequent import of fodder.
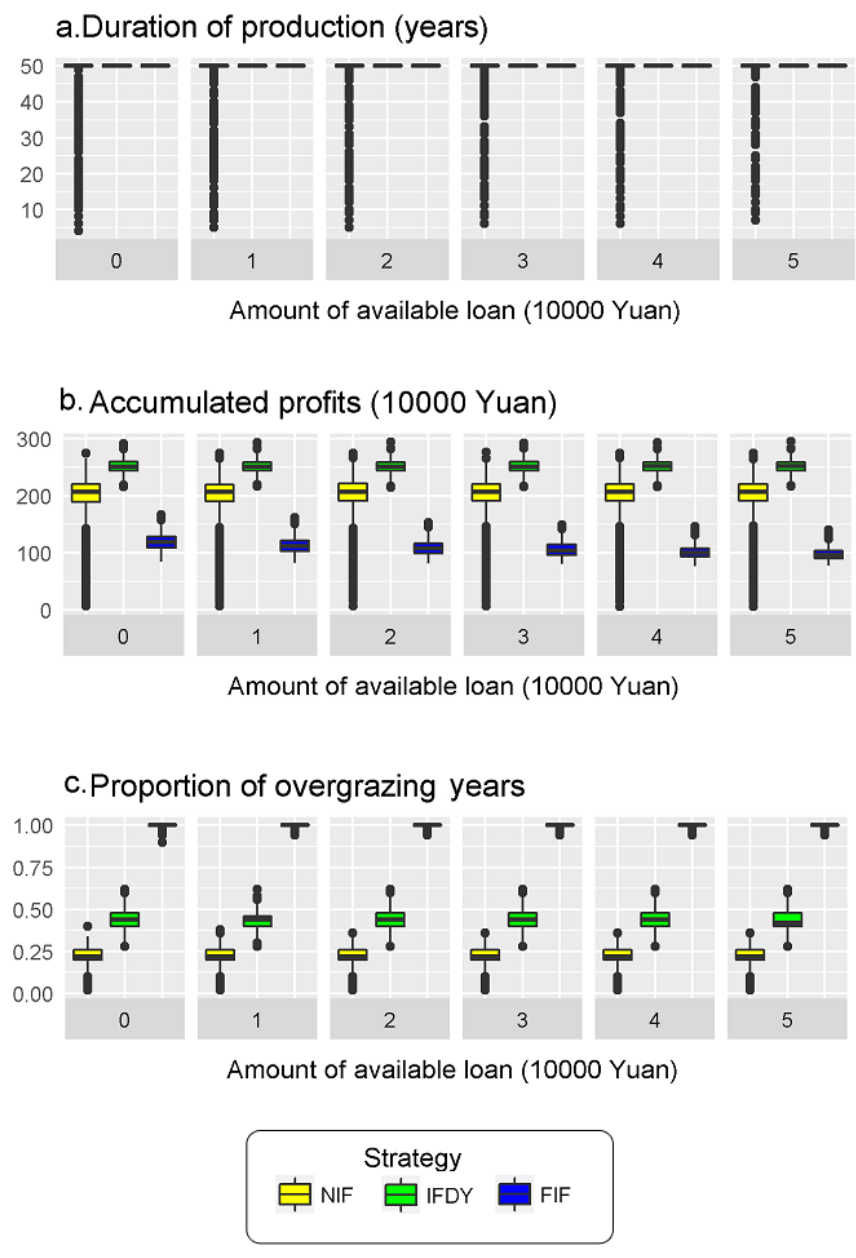

For households that imported fodder frequently (the FIF strategy), credit loans significantly increased the risk of bankruptcy, while reducing ecological risk and profits $(p<0.001$; blue boxplot, Fig. 6). The effects were increasingly obvious when the amount of available loan increased. When the amount of available loans increased from zero to $5 \times 10^{4}$ Yuan, the risk of bankruptcy increased from 65.6 to $100 \%$; the profits of production sharply decreased from $4.87 \times 10^{5}$ to $9.28 \times 10^{4}$ Yuan, and the average proportion of overgrazing years decreased from 32.0 to $16.7 \%$.

Results of the scenario with a doubled baseline livestock price When livestock prices doubled (Fig. 8), impacts of credit loans on pastoral systems were significantly different from the outcomes 
in the baseline scenario (Fig. 7). The impacts of credit loans were limited in general.

With no fodder import (the NIF strategy) and with available loans, the risk of bankruptcy slightly decreased $(p<0.001)$, and both profits of production and risk of rangeland degradation slightly increased $(p<0.001)$. The risk of bankruptcy decreased from $12.3 \%$ when no credit loans were available to $5.9 \%$ when the amount of available loans reached $5 \times 10^{4}$ Yuan $(\mathrm{p}<0.001)$. Profits increased from $1.95 \times 10^{6}$ to $2.01 \times 10^{6}$ Yuan. The average frequency of overgrazing increased from 21.8 to $22.52 \%$.

When fodder was imported in disaster years (the IFDY strategy), no significant changes were observed in any outcomes for all loan scenarios. Bankruptcy did not occur in any simulations, regardless of credit loan status. Average profits of production were around $2.51 \times 10^{6}$ Yuan for all loan scenarios. The average overgrazing years were about $43 \%$ for all loan scenarios.

When fodder was imported frequently (the FIF strategy), no significant changes were observed in the duration of production and frequency of overgrazing for all outcomes in different scenarios. No bankruptcy occurred. The profits of production were significantly lower when loans were available $(p<0.001)$ and decreased with increasing amount of available loans. But the level of change was minimal, and profits decreased from $1.19 \times 10^{6}$ Yuan with zero loans to $0.98 \times 10^{6}$ Yuan when the amount of available loan reached $5 \times 10^{4}$ Yuan. Overgrazing occurred in each year of simulation.

\section{Impacts of credit loan on the resilience of pastoral SES}

Impacts of credit loans depended on both fodder strategy and livestock price. When livestock prices were lower, credit loans could increase resilience of the SESs with the NIF or IFDY strategies, as they reduced the risk of bankruptcy and increased profits from production. Although ecological risk increased as well, the degree of increase was low. The overgrazing occurred only in $<27 \%$ of years with the IFDY strategy and in $13 \%$ of years with the NIF strategy. When the FIF strategy was adopted, credit loans increased vulnerability of the SESs to climate uncertainty. It increased the risk of bankruptcy significantly and led to a dramatic decline in profits. Although ecological risk was reduced as well, it was mainly due to the increase in the risk of bankruptcy.

Based on these outcomes, we concluded that the SES was more vulnerable to climate uncertainty when the FIF strategy was adopted and livestock prices were low. When livestock prices rose to a certain level (twice that of baseline prices used in this study), credit loans had few impacts on the SES in general. Loans increased slightly the resilience of the rangeland SES when the NIF strategy was adopted, and this was done by reducing the risk of bankruptcy and increasing profits at a low ecological risk. Loans reduced the resilience of the SES slightly when the FIF strategy was adopted, by reducing profits at a high ecological risk. Table 5 shows the changing impacts of credit loans for different fodder import strategies and livestock prices.

\section{DISCUSSION}

A pastoral system is a coupled social-ecological system (Fernández-Giménez 1997, Li and Li 2012, Li et al. 2015), in which the natural environment regulates and shapes pastoralists' production behavior, and the economic and social systems have evolved to adapt to the natural environments (Li and Zhang 2009). When external fodder is not available, herd size is determined by the primary productivity of natural rangelands; in turn, rangeland productivity is regulated by rainfall.

Table 5. Summary of impacts of credit loans.

\begin{tabular}{|c|c|c|c|c|}
\hline $\begin{array}{l}\text { Sheep price } \\
\text { scenario }\end{array}$ & Impacts & $\begin{array}{l}\text { No fodder } \\
\text { input }\end{array}$ & $\begin{array}{l}\text { Input fodder } \\
\text { in disaster } \\
\text { years }\end{array}$ & $\begin{array}{l}\text { Frequent } \\
\text { input of } \\
\text { fodder }\end{array}$ \\
\hline \multirow{4}{*}{$\begin{array}{l}\text { Low } \\
\text { (baseline) }\end{array}$} & Risk of bankruptcy & -- & - & ++++ \\
\hline & Profits & ++ & $+/$ No change & + \\
\hline & $\begin{array}{l}\text { Risk of rangeland } \\
\text { degradation }\end{array}$ & + & ++ & - \\
\hline & Resilience & +++ & ++ & - \\
\hline \multirow{4}{*}{$\begin{array}{l}\text { High } \\
\text { ( } 2 \text { times that } \\
\text { of baseline) }\end{array}$} & Risk of bankruptcy & - & No change & No change \\
\hline & Profits & No change & No change & - \\
\hline & $\begin{array}{l}\text { Risk of rangeland } \\
\text { degradation }\end{array}$ & No change & No change & No change \\
\hline & Resilience & + & No change & - \\
\hline
\end{tabular}

Note: - represents a decrease in value, + represents an increase in value, number of - or + represents the degree of decrease or increase.

Massive input of exogenous fodder and of financial resources induce new variables between nature and society and, as a result, decouple the pastoral production system from the rangeland ecosystem (Robinson et al. 2017). Importing fodder can alleviate the constraints of natural rangeland productivity in given climate conditions, and make the system heavily regulated by human activities. Credit loans further alleviate the constraints of cash flow (Sneath 2012), providing more options for household decision making. However, the needs for credit and interest payback contribute new variables to the household cash flow, which in turn affect the stocking rate and herd population dynamics (Murphy 2018). As the area and location of pastures became fixed after rangeland tenure change in our study area, and livestock mobility is prohibited (Li et al. 2007), an increase in herd size increases grazing intensity and the risk of rangeland degradation. Although current policies encourage fodder import and credit loans in an effort to manage climatic variability (Hazell 2000, State Council 2014, Ministry of Agriculture 2015, 2016), our results showed that the potential outcomes are more complex than expected.

\section{How does fodder input affect pastoral SES?}

\section{Livelihood risk}

Livestock serves as both end products and production materials in a pastoral system. Herd size determines fodder demands, production costs, and reproduction potential. A ewe or a cow needs a relatively long period (two to four years) to reach reproductive age. Therefore, adjustment of herd size and structure is the main approach of pastoralists to meeting their annual domestic needs while maintaining long-term reproduction potential and adapting to climatic variability (Perevolotsky 1986).

Maintaining herd size at a certain level is vital to sustaining pastoral production (Lybbert and Barrett 2007). Once the herd population decreases to a threshold, herd size cannot support the daily expenditures and production. If disasters continuously occur, herd size would decline if no fodder was imported. Even 
when optimal weather followed the disasters, herd size was too small to recover, leading to household bankruptcy. This explained why the risk of bankruptcy existed for all scenarios when no fodder was imported, regardless of livestock prices and credit loan availability. In the 1990s, many pastoralists in Mongolia (Sneath 2012) and Inner Mongolia (Williams 1997) lost their herds during natural disasters after the dismantling of herding collectives. This indicated that the risk of bankruptcy was high among pastoralists when mobility was limited and no fodder could be imported.

Purchased fodder serves as a "key resource" that sustains the herd when local forage is insufficient (Scooness 1994, Illius and O'Connor 1999) during drought or snow disasters; this helps to conserve key livestock assets (Carter and Barrett 2006). Therefore, importing of fodder in this study usually contributed to a reduced risk of bankruptcy. These findings are similar to the simulation results of Müller et al. (2015) and Schulze et al. (2016) in a semiarid rangeland of Morocco. Similarly, when livestock prices went up, the off-take rate declined as less livestock was sold to meet the daily life and production expenditures, which helped to keep the livestock population at a reproductive level, reducing the risk of bankruptcy.

\section{Production profits}

Profits from livestock production were affected by the duration of production, herd size, and livestock prices. The longer the production lasted (lower risk of bankruptcy), the more profits would be generated. Nevertheless, the relationship between production profits and herd size was nonlinear. Although an increase in herd size could increase gross output, it could also increase production costs, because a larger herd needs more expenditures for veterinary services, energy, labor, and emergency fodder during disasters. When livestock prices went up, pastoralists would have more cash to cover production costs and life expenditures with less livestock sale; this could help to increase herd size, reduce the risk of bankruptcy, and increase the profits. However, when livestock prices further increased and so did herd size, negative impacts caused by herd size also increased, e.g., higher costs of regular production and disaster coping emerged. Therefore, with increasing livestock prices, herd size may exceed a certain threshold and the negative contribution of increasing costs would surpass the benefits of a reduced risk of bankruptcy, leading to a decline in net profits of pastoral production.

With the NIF and IFDY strategies, herd size would be constrained either by natural disasters (the NIF strategy) or management approaches (the IFDY strategy). Therefore, production profits could constantly increase when livestock prices went up until the herd size reached the level of constraint. With the FIF strategy of importing fodder whenever a forage gap occurred, herd size was no longer constrained by either natural conditions or management. Higher livestock prices made it easier for pastoralists to earn money to buy more fodder and to maintain larger herd sizes. Once herd size surpassed a certain level, production profits would decline because of increasing fodder costs, especially when continuous natural disasters occurred.

This finding suggests that the dynamics of pastoral systems are nonlinear; there may exist an optimal level of fodder input and a threshold herd size for sustainable livestock production. However, these optimal levels or thresholds are not fixed; instead, they depend on multiple social, economic, and environmental factors, and are dynamic. Establishing an adaptive management strategy, such as importing of fodder according to weather conditions, is a more reasonable approach.

\section{Ecological risk}

Because of the limitations of available data, we used grazing intensity as a proxy for assessing ecological risk. Because the area of the household pasture was a constant in the model, grazing intensity was mainly affected by herd size and rainfall amounts. When fodder was imported, herd size tended to increase, therefore, ecological risk also increased. This result was consistent with that from other pastoral areas of northern Asia (Seligman and Perevolosky 1994, Kerven 2004, Yu et al. 2004, Wang 2006) and Africa (Müller et al. 2015, Schulze et al. 2016), i.e., supplementary fodder increased the risk of rangeland degradation.

If fodder was imported only in disaster years (the IFDY strategy), herd size remained constrained by natural conditions. Therefore, although ecological risk increased with the IFDY compared to the no fodder import strategy, it was not as dramatic as with the frequent import of fodder strategy in which herd size fully overcame natural constraints. This result was similar to the findings by Schulze et al. (2016) who reported lower biomass regeneration ability with a "feeding when needed" strategy than with a "feeding in drought" strategy. This supports the arguments of the nonequilibrium theory (Ellis and Swift 1988) that natural fluctuation would adjust herd size in arid rangelands so that grazing contributed little to rangeland degradation in the long term. It also supported the statements by Illius and O'Connor (2000) and Müller et al. (2007) that the risk of rangeland degradation increased with the proportion of key resources in the system.

It is worth noting that we did not simulate feedbacks of grazing pressure to rangeland vegetation. Schulze et al. (2016) reported a decline in biomass and herd size with the "feeding in drought" strategy after 40 years of simulation. The resilience of vegetation and soil to grazing mediates the impacts of stocking on long-term ecosystem health (West 2003, Vetter 2005). Future studies that incorporate feedbacks of grazing to vegetation in arid steppe rangeland may be necessary.

\section{How do credit loans affect pastoral SES?}

Credit loans have been recommended as an approach to facilitate rural development and a financial tool to help smallholders adapt to climate change in rural areas (World Bank 2007, Santos and Barrett 2011, Addison and Brown 2014). Theoretically, when credit loans were available, pastoralists could use them to move livestock to other places when drought occurred, thus avoiding the need to sell a large stock at a low price, and be able to keep a larger herd. In the recovery period after a natural disaster, pastoralists could use credit loans to meet their living needs, and to reduce livestock sale, thus making it possible to recover the herd rapidly.

However, the results were confounded by the highly variable and uncertain climate. As the simulation results revealed, the impacts of credit loans highly depended on livestock prices and fodder strategies. When livestock prices were low and no fodders were imported (the NIF strategy) or the amount of fodder import was lower (the IFDY strategy), credit loans helped the household to keep a reasonable herd size during disasters and to recover rapidly 
afterward. However, if fodder was imported frequently (the FIF strategy), keeping a large herd size by importing large amounts of fodder would increase production costs when natural disaster occurred. Because climate is highly variable and unpredictable, and pastoralists cannot predict conditions in future years, maximizing the number of breeding ewes is a logical approach to guarantee future production (Ellis and Swift 1988, Allsopp et al. 2007, Harris 2010). Without a deliberate control on herd size, access to credit loans would help pastoralists to enlarge their herd initially. However, when disaster occurred, pastoralists had to sell even more livestock to repay the loans and interests, and entered a destructive cycle of "borrow money - buy fodder - sell livestock - borrow money" (Zhang et al. 2018). That is why the risk of bankruptcy dramatically increased with the amount of the credit loans under the FIF strategy. This finding was similar to those of Sneath (2012) and Murphy (2018) in Mongolia, who found that loans amplified pastoral vulnerability in the environment where natural disasters frequently occurred. An empirical case study in a semiarid rangeland of Inner Mongolia of China by Zhang et al. (2018) also reported that cumulative impacts of repayment pressure, as well as weather and market uncertainty, led to reduced herd sizes and/or larger loans.

When livestock prices increased, it was easier for pastoralists to pay back the loans and maintain a larger herd size even though they had to afford higher production costs. Profits from selling of nonproductive livestock could meet the living needs and production costs in most cases, reducing the role of credit loans to insignificant. With the no import of fodder strategy, credit loans helped households to reduce livestock sale in continuous poor years, and higher livestock prices guaranteed that households were able to pay back the loan. Therefore, households were able to maintain herd size above the critical threshold, decreasing the risk of bankruptcy with increasing amount of available credit, which further contributed to an increase in ecological risks and profits of production. With the strategy of importing fodder only in disaster years, households could maintain production using profits from selling nonproductive livestock, and credit loans did not affect pastoral SES.

Higher livestock prices eliminated the risk of bankruptcy, and ecological risk reached $100 \%$ with the strategy of frequent import of fodder without credit loans. Credit loans could not improve the livelihood and led to further deterioration of ecological conditions in this scenario. In addition, larger herd sizes induced higher production costs, especially when disasters occurred, which reduced production profits. In fact, livestock depended mainly on imported fodder in this scenario, while forage from the natural pasture contributed only a minor part of the total feed consumed.

\section{CONCLUSIONS AND POLICY IMPLICATIONS}

Based on an agent-based model and Monte Carlo simulations, we assessed the impacts of importing fodder and using credit loans on the resilience of the pastoral SES in conditions of climatic variability and uncertainty. We found that fodder import and credit loans function positively only under some conditions, and may have negative effects under other conditions. The strategy of purchasing fodder only in climatic disaster years could enhance the resilience of pastoral SES by increasing production profits and reducing the risk of bankruptcy, while frequent fodder input in normal years would increase the vulnerability of the pastoral SES because of increased ecological risk and potential reduction in profits.

The impacts of credit loans depended on the levels of fodder input and livestock prices. When livestock prices were low, loans enhanced the resilience of the SES when no import fodder was used or when it was used only in disaster years, but they reduced the resilience if fodder was imported as a regular strategy even in normal years. When livestock price reached a certain level, credit loans had few impacts on the SES regardless of fodder strategies adopted.

Pastoral SESs are increasingly embedded into the regional and national markets (Robinson et al. 2017). It is increasingly easier for the pastoralists to buy fodder and obtain credit loan services on the market, and market development is usually promoted by governments (Hazell and Hess 2010, Briske et al. 2015). Although importing fodder and access to loan services may enhance the resilience of the pastoral SES to climatic variability, they work only under some preconditions, for example, when fodder is imported only in disaster years. The government could guide the pastoralists to adoption of the IFDY strategy. Intensive animal husbandry, which is highly dependent on supplementary fodder, should not be encouraged and should not replace extensive husbandry in the highly climatically variable arid areas.

Credit loans alone are unlikely to be an effective tool in addressing climate variability because they may increase the vulnerability of pastoralists when combined with disasters, low livestock prices, and unsuitable fodder strategies. Appropriate stocking strategies that adapt to the local environment may be a precondition for a credit loan to be effective.

Pastoral production is a dynamic adaptive system. The relationships between herd size, cash flow, and profits are nonlinear. There may be an optimal level of fodder input and a threshold of herd size to sustain livestock production. However, these thresholds are not a fixed value; instead, they depend on multiple social, economic, and environmental factors, all of which have their own dynamic. Applying adaptive management strategies, such as the strategy of importing fodder only in disaster years, is a more reasonable approach.

Promoting higher livestock prices could help to enhance the resilience of the pastoral SES in preconditions of controlling the amount of fodder import and herd size. Marketing of the products from a pastoral area, such as organic beef and milk, might contribute to higher livestock products prices.

Our model was based on parameters unique to a desert steppe (arid region) with low precipitation and highly variable primary productivity. A few studies in a typical steppe of Inner Mongolia (semiarid region) had similar findings (Zhang et al. 2018, Lu 2020). The application of these findings in pastoral areas with higher precipitation and more stable primary productivity needs to be further explored. In addition, we assumed static livestock prices, living costs, and production material prices (except for fodder) to simplify the model and we did not consider the impacts of rangeland management policies. The interactions between the variability in both environment and human subsystems drive the level of damage from natural disasters (Stafford Smith et al 2007). Further modeling that incorporates the variability in livestock 
prices as well as policy aspects will help to further increase the understanding of the dynamics of pastoral systems.

Responses to this article can be read online at: https://www.ecologyandsociety.org/issues/responses. php/12245

\section{Acknowledgments:}

This study was funded by Nature Science Foundation of China (grant number: 41671522 \& 41971256). The authors would like to thank Chengcheng Zhang, Cheng Zhang, Tao Wang, Yupei Lai, and Yucheng Gu for their assistance in field work; and professor Daniel O Suman of the University of Miami and Dr. Kathryn Piatek for language editing.

\section{Data Availability:}

The datalcode that support the findings of this study are openly available in CoMSES Network at https://www.comses.netl codebases/2c34b392-54ba-40ef-9a63-4f7d1f43c625/releases/1.0.01.

\section{LITERATURE CITED}

Addison, J., and C. Brown. 2014. A multi-scaled analysis of the effect of climate, commodity prices and risk on the livelihoods of Mongolian pastoralists. Journal of Arid Environments 109:54-64. https://doi.org/10.1016/i.jaridenv.2014.05.010

Agrawal, A. 2010. Local institution and adaptation to climate change. Pages 173-197 in R. Mearns and A. Norton, editors. Social dimensions of climate change. World Bank, Washington, D.C., USA.

Ahearn, A. 2018. Herders and hazards: covariate $d z u d$ risk and the cost of risk management strategies in a Mongolian subdistrict. Natural Hazards 92:165-181. https://doi.org/10.1007/s11069-017-3128-4

Allsopp, N., C. Laurent, L. M. C. Debeaudoin, and M. I. Samuels. 2007. Environmental perceptions and practices of livestock keepers on the Namaqualand Commons challenge conventional rangeland management. Journal of Arid Environment 70:740-754. https://doi.org/10.1016/j.jaridenv.2006.11.005

Bai, Y., J. Wu, Q. Xing, Q. Pan, J. Huang, D. Yang, and X. Han. 2008. Primary production and rain use efficiency across a precipitation gradient on the Mongolia Plateau. Ecology 89 (8):2140-2153. https://doi.org/10.1890/07-0992.1

Barrett, C. B., and W. K. Luseno. 2004. Decomposing producer price risk: a policy analysis tool with an application to northern Kenyan livestock markets. Food Policy 29:393-405. https://doi. org/10.1016/j.foodpol.2004.07.008

Basil, M., and A. Jamieson. 1999. Uncertainty of complex systems by Monte Carlo simulation. Measurement and Control 32:16-20. https://doi.org/10.1177/002029409903200104

Behnke, R. H., and M. Mortimore, editors. 2016. The end of desertification? Disputing environmental change in the drylands. Springer-Verlag, Berlin, Germany. https://doi.org/10.1007/978-3-642-16014-1
Boone, R. B., K. A. Galvin, S. B. BurnSilver, P. K. Thornton, D. S. Ojima, and J. R. Jawson. 2011. Using coupled simulation models to link pastoral decision making and ecosystem services. Ecology and Society 16(2):6. https://doi.org/10.5751/ES-04035-160206

Briske, D. D., M. Zhao, G. Han, C. Xiu, D. R. Kemp, W. Willms, K. Havstad, L. Kang, Z. Wang, J. Wu, X. Han, and Y. Bai. 2015. Strategies to alleviate poverty and grassland degradation in Inner Mongolia: intensification vs production efficiency of livestock systems. Journal of Environmental Management 152:177-182. https://doi.org/10.1016/j.jenvman.2014.07.036

Bureau of Standard Measurement of Inner Mongolia. 1990. Calculation standard of proper carrying capacity in Inner Mongolia [Title translated from the Chinese by the authors]. Honhot, Inner Mongolian, China.

Carter, M. R. and C. B. Barrett. 2006. The economics of poverty traps and persistent poverty: an asset-based approach. Journal of Development Studies 42(2):178-199. https://doi.org/10.1080/00220380500405261

Christensen, L., M. B. Coughenour, J. E. Ellis, and Z. Chen. 2003. Sustainability of Inner Mongolian grasslands: application of the savanna model. Journal of Range Management 56(4):319-327. https://doi.org/10.2458/azu jrm v56i4 christensen

Compiling Committee of Annals of Sonid Left Banner. 2004. Annals of Sonid Left Banner [Title translated from the Chinese by the authors]. Cultural Press of Inner Mongolia, Honhot, Inner Mongolian, China.

Dercon, S., and P. Krishnan. 1996. Income portfolios in rural Ethiopia and Tanzania: choices and constraints. Journal of Development Studies 32(6):850-875. https://doi.org/10.1080/00220389608422443

Díaz-Solís, H., W. E. Grant, M. M. Kothmann, W. R. Teague, and J. A. Díaz-García. 2009. Adaptive management of stocking rates to reduce effects of drought on cow-calf production systems in semi-arid rangelands. Agricultural Systems 100(1-3):43-50. https://doi.org/10.1016/j.agsy.2008.12.007

Dupas, P., and J. Robinson. 2013. Why don't the poor save more? Evidence from health savings experiments. American Economic Review 103:1138-1171. https://doi.org/10.1257/aer.103.4.1138

Ellis, J. E., and D. M. Swift. 1988. Stability of African pastoral ecosystems: alternate paradigms and implications for development. Journal of Range Management 41(6):450-459. https://doi.org/10.2307/3899515

Fernández-Giménez, M. E. 1997. Landscapes, livestock, and livelihoods: social, ecological, and land-use change among the nomadic pastoralists of Mongolia. University of California, Berkeley, California, USA.

Fernández-Giménez, M. E. 2001. The effects of livestock privatization on pastoral land use and land tenure in post-socialist Mongolia. Nomadic Peoples 5(2):49-66. https://doi. org/10.3167/082279401782310862

Fernández-Giménez, M. E. and D. M. Swift. 2003. Strategies for sustainable grazing management in the developing world. Proceedings of the VIIth International Rangelands Congress. Durban, South Africa. 
Gongbuzeren, Y. Li, and W. Li. 2015. China's rangeland management policy debates: What have we learned? Rangeland Ecology and Management 68:305-314. https://doi.org/10.1016/j. rama.2015.05.007

Gongbuzeren, Z. Zhang, and J. Wu. 2020. How do market-based rangeland institutional reforms affect herders engagement with credit loans within the pastoral regions of the Tibetan Plateau. Journal of Rural Studies 73:1-9. https://doi.org/10.1016/j. jrurstud.2019.11.015

Grimm, V., U. Berger, F. Bastiansen, S. Eliassen, V. Ginot, J. Giske, J. Goss-Custard, T. Grand, S. K. Heinz, G. Huse, et al. 2006. A standard protocol for describing individual-based and agentbased models. Ecological Modelling 198(1-2):115-126. https://doi. org/10.1016/j.ecolmodel.2006.04.023

Hahn, B. D., F. D. Richardson, M. T. Hoffman, R. Roberts, S. W. Todd, and P. J. Carrick. 2005. A simulation model of long-term climate, livestock and vegetation interactions on communal rangelands in the semi-arid Succulent Karoo, Namaqualand, South Africa. Ecological Modelling 183(2-3):211-230. https://doi. org/10.1016/j.ecolmodel.2004.07.028

Han, N. Y. 2011. The logic of grassland [Title translated from the Chinese by the authors]. Beijing Science and Technology Press, Beijing, China.

Hannig, A., and S. Jansen. 2010. Financial inclusion and financial stability: current policy issues. ADBI Working Paper, Vol. 259. Asian Development Bank Institute, Tokyo, Japan. https://doi. org/10.2139/ssrn.1729122

Harris, R. B. 2010. Rangeland degradation on the QinghaiTibetan plateau: a review of the evidence of its magnitude and causes. Journal of Arid Environment 74:1-12. https://doi. org/10.1016/j.jaridenv.2009.06.014

Hazell, P. 2000. Public policy and drought management in agropastoral systems. Pages 86-101 in N. McCarthy, B. Swallow, M. Kirk, P. Hazell, editors. Property rights, risk, and livestock development in Africa. International Food Policy Research Institute, Washington, D.C., USA.

Hazell, P. B. R., and U. Hess. 2010. Drought insurance for agricultural development and food security in dryland areas. Food Security 2:395-405. https://doi.org/10.1007/s12571-010-0087-y

Horn, B. E., C. R. Hart, and S. I. Paisley. 2003. Management of rangeland livestock under drought. Annals of Arid Zone 41:1-23.

Hou, X., Y. Han, and F. Y. Li. 2012. The perception and adaptation of herdsmen to climate change and climate variability in the desert steppe region of northern China. Rangeland Journal 34(4):349-357. https://doi.org/10.1071/RJ12013

Illius, A. W., and T. G. O'Connor. 1999. On the relevance of nonequilibrium concepts to arid and semiarid grazing systems. Ecological Applications 9:798-813. https://doi.org/10.1890/1051-0761 (1999)009[0798:OTRONC]2.0.CO;2

Illius, A. W., and T. G. O'Connor. 2000. Resource heterogeneity and ungulate population dynamics. OIKOS 89:283-294. https:// doi.org/10.1034/j.1600-0706.2000.890209.x
Jimoh, S. O., Y. Yin, P. Li, T. O. Muraina, and X. Hou. 2020. Understanding stocking rate in response to supplementary feed in Inner Mongolia, China. Rangeland Journal 42:135-142. https:// doi.org/10.1071/RJ19084

Karimi, V., E. Karami, and M. Keshavarz. 2018. Vulnerability and adaptation of livestock producers to climate variability and change. Rangeland Ecology \& Management 71:175-184. https:// doi.org/10.1016/j.rama.2017.09.006

Kerven, C. 2004. The influence of cold temperatures and snowstorms on rangelands and livestock in northern Asia. In $\mathrm{S}$. Vedder, editor. Rangelands at equilibrium and non-equilibrium: recent developments in the debate around rangeland ecology and management. Papers from the International Workshop held at the VIIth International Rangeland Congress in Durban, 26-27 July 2003. Programme for Land and Agrarian Studies, Bellville, South Africa.

Kraetli, S., and N. Schareika. 2010. Living off uncertainty: the intelligent animal production of dryland pastoralists. European Journal of Development Research 22:605-622. https://doi. org/10.1057/ejdr.2010.41

Le Houerou, H. N. 1984. Rain use efficiency: a unifying concept in arid-land ecology. Journal of Arid Environments 7:213-247.

Li, W. J., S. H. Ali, and Q. Zhang. 2007. Property rights and grassland degradation: a study of the Xilingol Pasture, Inner Mongolia, China. Journal of Environmental Management 85 (2):461-470. https://doi.org/10.1016/j.jenvman.2006.10.010

Li, W., and L. Huntsinger. 2011. China's grassland contract policy and its impacts on herder ability to benefit in Inner Mongolia: tragic feedbacks. Ecology and Society 16(2):1. https://doi. org/10.5751/es-03969-160201

Li, W., and Y. Li. 2012. Managing rangeland as a complex system: how government interventions decouple social systems from ecological systems. Ecology and Society 17(1):9. https://doi. org/10.5751/ES-04531-170109

Li, W. J., and Q. Zhang. 2009. Understanding the dilemmas on rangeland: discussion on some problems on utilization and management of arid and semi-arid rangeland [Title translated from the Chinese by the authors]. Economy and Science Press, Beijing, China.

Li, Y. 2019. A pastoral stoking strategy model with fodder import and loan scenarios v1.0.0. CoMSES Computational Model Library. [online] URL: https://www.comses.net/codebases/2c34b392-54ba-40ef-9a63-4f7d1f43c625/releases/1.0.0/

Li, Y., M. Fan, and W. Li. 2015. Application of payment for ecosystem services in China's rangeland conservation initiatives: a social-ecological system perspective. Rangeland Journal 37 (3):285-296. https://doi.org/10.1071/RJ14014

Lu, Y. 2020. Microcredit's impacts on rangeland social-ecological systems in arid areas [Title translated from the Chinese by the authors]. Dissertation. Peking University, Beijing, China.

Luan, D. X., and S. Bauer. 2016. Does credit access affect household income homogeneously across different groups of credit recipients? Evidence from rural Vietnam. Journal of Rural Studies 47:186-203. https://doi.org/10.1016/j.jrurstud.2016.08.001 
Lybbert, T. J., and C. B. Barrett. 2007. Risk responses to dynamic asset thresholds. Review of Agricultural Economics 29:412-418. https://doi.org/10.1111/j.1467-9353.2007.00354.x

Ministry of Agriculture. 2015. Opinions of Ministry of Agriculture on improving development of grazing animal husbandry. Ministry of Agriculture, Beijing, China. [online] URL: http://www.moa. gov.cn/nybgb/2015/wu/201712/t20171219 6103835.htm

Ministry of Agriculture. 2016. National development plan of grazing animal husbandry in China (2016-2020). Ministry of Agriculture, Beijing, China. [online] URL: http://www.moa.gov. cn/nybgb/2016/dibaqi/201712/t20171219 6102799.htm

Müller, B., A. Linstädter, K. Frank, M. Bollig, and C. Wissel. 2007. Learning from local knowledge: modeling the pastoralnomadic range management of the Himba, Namibia. Ecological Applications 17(7):1857-1875. https://doi.org/10.1890/06-1193.1

Müller, B., J. Schulze, D. Kreuer, A. Linstädter, and K. Frank. 2015. How to avoid unsustainable side effects of managing climate risk in drylands - the supplementary feeding controversy. Agricultural Systems 139:153-165. https://doi.org/10.1016/j. agsy.2015.07.001

Murphy, D. J. 2018. "We're living from loan-to-loan": pastoral vulnerability and the cashmere-debt cycle in Mongolia. Individual and Social Adaptations to Human Vulnerability 38:7-30. https:// doi.org/10.1108/S0190-128120180000038002

Perevolotsky, A. 1986. To sell or not to sell-a pastoralist's dilemma: a lesson from the slaughterhouse. Human Ecology 14 (3):287-310. https://doi.org/10.1007/bf00889032

Reynolds, J. F., D. M. Stafford Smith, E. F. Lambin, B. L. Turner II, M. Mortimore, and S. P. J. Batterbury, T. E. Downing, H. Dowlatabadi, R. J. Fernández, J. E. Herrick, et al. 2007. Global desertification: building a science for dryland development. Science 316(5826):847-851. https://doi.org/10.1126/science.1131634

Robinson, B. E., P. Li, and X. Hou. 2017. Institutional change in social-ecological systems: the evolution of grassland management in Inner Mongolia. Global Environmental Change 47:64-75. https://doi.org/10.1016/j.gloenvcha.2017.08.012

Santos, P., and C. B. Barrett. 2011. Persistent poverty and informal credit. Journal of Development Economics 96:337-347. https://doi. org/10.1016/j.jdeveco.2010.08.017

Schade, B., and T. Wiesenthal. 2011. Biofuels: a model based assessment under uncertainty applying the Monte Carlo method. Journal of Policy Modeling 33(1):92-126. https://doi.org/10.1016/ j.jpolmod.2010.10.008

Schulze, J., K. Frank, and B. Müller. 2016. Governmental response to climate risk: model-based assessment of livestock supplementation in drylands. Land Use Policy 54:47-57. https:// doi.org/10.1016/j.landusepol.2016.01.007

Scoones, I. 1994. Living with uncertainty: new directions in pastoral development in Africa. Intermediate Technology Publications, London, UK. https://doi.org/10.3362/9781780445335

Seligman, N. G., and A. Perevolosky. 1994. Has intensive grazing by domestic livestock degraded the Mediterranean basin rangelands? Pages 93-103 in M. Arianoutsou and R. H. Groves, editors. Plant-animal interactions in Mediterranean-type ecosystems. Spring, Dordrecht, The Netherlands. https://doi. org/10.1007/978-94-011-0908-6 9

Smit, B., and J. Wandel. 2006. Adaptation, adaptive capacity and vulnerability. Global Environmental Change 16(3):282-292. https://doi.org/10.1016/j.gloenvcha.2006.03.008

Sneath, D. 2012. The 'age of the market' and the regime of debt: the role of credit in the transformation of pastoral Mongolia. Social Anthropology 20(4):458-473. https://doi.org/10.1111/ j.1469-8676.2012.00223.X

Stafford Smith, D. M. S., G. M. McKeon, I. W. Watson, B. K. Henry, G. S. Stone, W. B. Hall, and S. M. Howden. 2007. Learning from episodes of degradation and recovery in variable Australian rangelands. Proceedings of the National Academy of Sciences 104 (52):20690-20695. https://doi.org/10.1073/pnas.0704837104

State Council. 2014. Establishment of implementation strategies for targeted measures in rural poverty reduction [Title translated from the Chinese by the authors]. State Council, Beijing, China.

Sun, J. Z. 1988. Climate of animal husbandry in the grassland of Inner Mongolia [Title translated from the Chinese by the authors]. Geography Studies 7(1):36-45.

Thornton, P. K., J. van de Steeg, A. Notenbaert, and M. Herrero. 2009. The impacts of climate change on livestock and livestock systems in developing countries: a review of what we know and what we need to know. Agricultural Systems 101(3):113-127. https://doi.org/10.1016/j.agsy.2009.05.002

Vetter, S. 2005. Rangelands at equilibrium and non-equilibrium: recent developments in the debate. Journal of Arid Environments 62:321-341. https://doi.org/10.1016/j.jaridenv.2004.11.015

Walker, B. H., L. H. Gunderson, A. P. Kinzig, C. Folke, S. R. Carpenter, and L. Schultz. 2006. A handful of heuristics and some propositions for understanding resilience in social-ecological systems. Ecology and Society 11(1):13. https://doi.org/10.5751/ ES-01530-110113

Wang, J. G. 2006. Agro-pastoral ecology and traditional Mongolian society [Title translated from the Chinese by the authors]. Shandong People's University Press, Jinan, Shandong, China.

Wang, J., D. G. Brown, and A. Agrawal. 2013. Climate adaptation, local institutions, and rural livelihoods: a comparative study of herder communities in Mongolia and Inner Mongolia, China. Global Environmental Change 23(6):1673-1683. https://doi. org/10.1016/j.gloenvcha.2013.08.014

Wang, T. 2011. Analysis on the impacts of pastoralists' adaptive capacity to climate change under government interventions: a case study in Hexigten Banner, Inner Mongolia [Title translated from the Chinese by the authors]. Peking University, Beijing, China.

West, N. E. 2003. Theoretical underpinnings of rangeland monitoring. Arid Land Research and Management 17(4):333-346. https://doi.org/10.1080/713936112

Williams, D. M. 1997. Grazing the body: violations of land and limb in Inner Mongolia. American Ethnologist 24(4):763-785. https://doi.org/10.1525/ae.1997.24.4.763 
World Bank. 2007. Vietnam: developing a comprehensive strategy to expand access [for the poor] to microfinance services. World Bank, Washington, D.C., USA.

World Bank. 2014. Global financial development report 2014: financial inclusion. World Bank, Washington, D.C., USA. https:// doi.org/10.1596/978-1-4648-0484-7 global financial development

Xie, Y., and W. Li. 2008. Why do herders insist on Otor? Maintaining mobility in Inner Mongolia. Nomadic Peoples 12 (2):35-52. https://doi.org/10.3167/np.2008.120203

Yu, M., J. E. Ellis, and H. E. Epstein. 2004. Regional analysis of climate, primary production, and livestock density in Inner Mongolia. Journal of Environmental Quality 33:1675-1681. https://doi.org/10.2134/jeq2004.1675

Zhang, C., W. Li, and M. Fan. 2013. Adaptation of herders to droughts and privatization of rangeland-use rights in the arid Alxa Left Banner of Inner Mongolia. Journal of Environmental Management 126:182-190. https://doi.org/10.1016/j.jenvman.2013.04.053

Zhang, J., L. Huntsinger, Y. Li, and W. Li. 2018. Is microcredit a form of risk for pastoral households of Inner Mongolia's semiarid rangelands? Rangeland Ecology \& Management 71(3):382-388. https://doi.org/10.1016/j.rama.2017.12.011 
Appendix 1. Explanations of the formulas in Figure 2.

Figure 2 shows the decision process of amounts of livestock to sale, fodder to buy and money to borrow with different stocking strategies. With input of information of herd, usable forage on pastures, price of sheep and forage, available loan, and household cash flow, the agent will decide the amounts of livestock to sale $(\mathrm{Qs})$, forage to buy $\left(\mathrm{F}_{\text {input }}\right)$ and money to borrow $(\mathrm{L})$. There are three constrictions that the agent must follow: (1) all the old and sick sheep $\left(\mathrm{Q}_{1}\right)$ will be sold to maximize the future productivity of the herd; (2) The fodder supply, including the forage on pastures $\left(\mathrm{F}_{\text {pasture }}\right)$ and the fodder purchased from market $\left(\mathrm{F}_{\text {input }}\right)$, should be no less than the fodder demand by the herd; and (3) the available cash (including net income and loans), should be no less than expenditures (including domestic expenditures and loans to pay back).

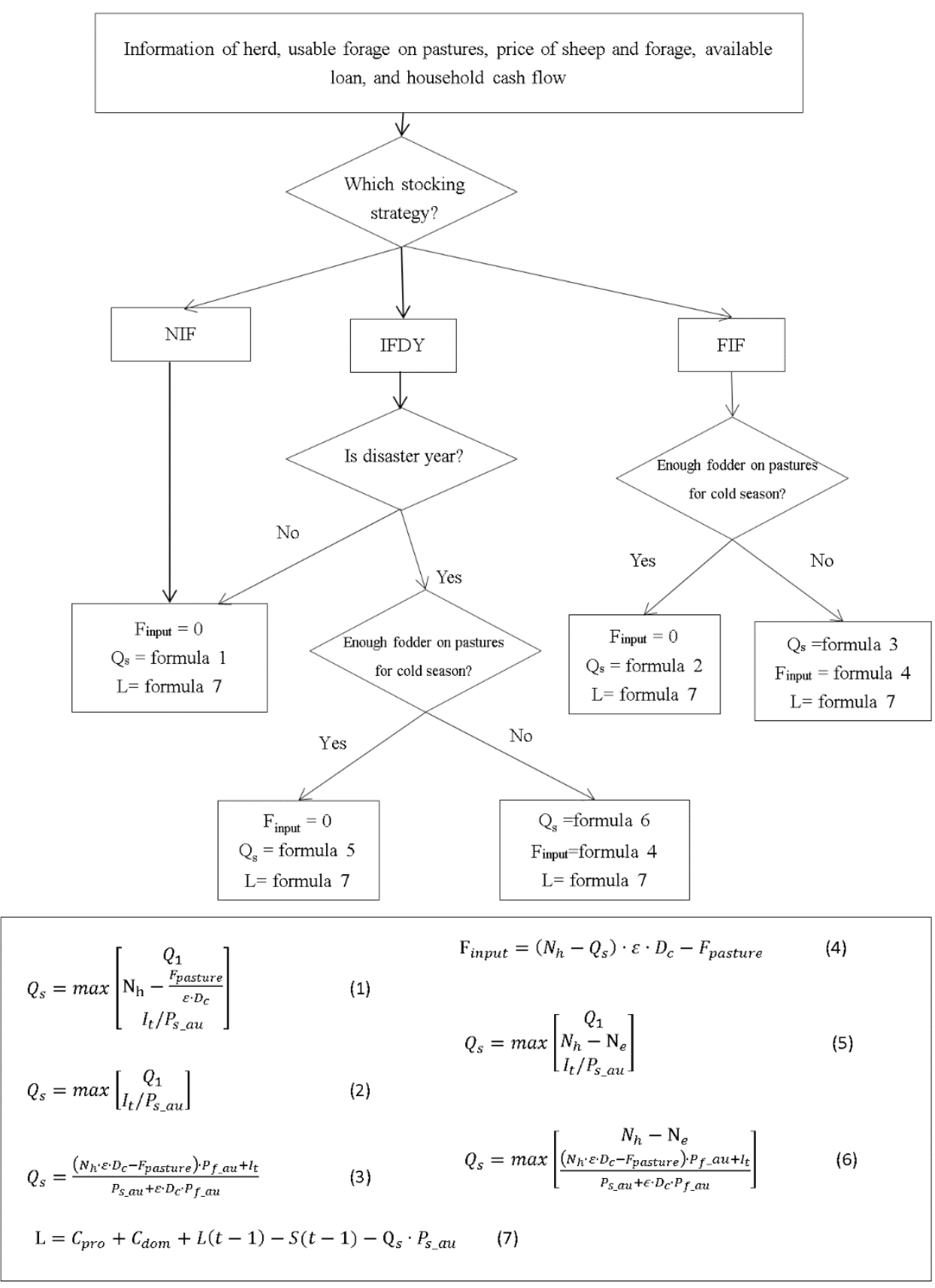


Figure 2. Flow chart of the processes of the agents' stocking decision. With input of information, the agents with different stocking strategies decide how much livestock to sale and forage to buy according to the decision process and the formulas. NIF- no import of forage, FIDY- import forage only in disaster years, FIF-import of forage whenever forage gap exist, $\mathrm{F}_{\text {input- }}$ amount of purchased forage, $\mathrm{O}_{\mathrm{s}^{-}}$total number of sheep to sale, $\mathrm{L}$-amount of money to borrow, $\mathrm{F}_{\text {pasure }}$ usable forage from pastures in cold season., $\mathrm{N}_{\mathrm{h}}-$ total number of sheep, $\mathrm{Q}_{1}$ - number of sheep to sale at first stage, is the sum of the number of the old, the sick and male lamb. $\varepsilon$ - daily intake of a sheep, $D_{c}-$ total days in cold season, $\mathrm{I}_{\mathrm{t}}-$ target income, $\mathrm{I}_{\mathrm{t}}=$ total production costs before fodder purchase + living expenditures + savings of the previous year+ loan (if exist) - available loan, $\mathrm{P}_{\mathrm{s}_{\text {au }}}$ - price of sheep in autumn, $\mathrm{P}_{\mathrm{f} \_} \mathrm{au}$ - price of forage in autumn, $\mathrm{N}_{\mathrm{e}^{-}}$number of ewes at the beginning of the year, $\mathrm{C}_{\text {pro- }}$ production costs, $\mathrm{C}_{\mathrm{dom}^{-}}$family expenditures, $\mathrm{L}(\mathrm{t}-1)-$ loans of the previous year, $\mathrm{S}(\mathrm{t}-1)$ - savings of the previous year.

\section{Decisions with the 'No import of fodder' (NIF) strategy}

If the 'No import of fodder' (NIF) strategy is adopted, no fodder will be inputted, thus, $\mathrm{F}_{\text {input }}=$ 0 . The number of sheep to sale is the biggest one among $Q_{1}$, the total number of sheep $\left(\mathrm{N}_{\mathrm{h}}\right)$ minus the number of sheep that pastures could support $\left(\mathrm{F}_{\text {pasture }}(\mathcal{E} \cdot \mathrm{Dc})\right)$, in which $\varepsilon$ is daily intake of a sheep and Dc is days in cold season), and the number determined by the need of cash $\left(\mathrm{I}_{\mathrm{t}} / \mathrm{P}_{\mathrm{s} \text {-au }}\right)$, where $\mathrm{I}_{\mathrm{t}}$ is target income, which represents the amount of money that the agent have to earn to cover production costs and domestic expenditures. $\mathrm{I}_{\mathrm{t}}=$ total production costs except for fodder costs in autumn+ living expenditures + savings of the previous year + loan (if exist) - available loan, $\mathrm{P}_{\mathrm{s}-\mathrm{au}}$ is price of sheep in autumn.)

Amount of money to borrow (L) is determined by the total production costs $\left(\mathrm{C}_{\mathrm{pro}}\right)+$ family expenditures $\left(\mathrm{C}_{\mathrm{dom}}\right)+$ loan of the previous year $(\mathrm{L}(\mathrm{t}-1))$ - savings of the previous year $(\mathrm{S}(\mathrm{t}-1))$ -

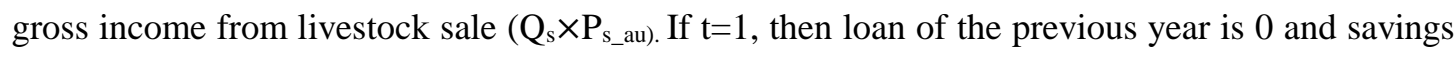
of the previous year is 20000 yuan as set during initialization.

\section{Decisions with the 'frequent import of fodder' (FIF) strategy}

If the 'frequent import of fodder' (FIF) strategy was adopted, $F_{\text {input, }} \mathrm{Q}_{\mathrm{s}}$ and $\mathrm{L}$ is further determined by usable forage on pastures for cold season and fodder demand. If there are enough fodder on pastures for cold season $\left(\left(\mathrm{N}_{\mathrm{h}}-\mathrm{Q}_{1}\right) \cdot \varepsilon \cdot \mathrm{D}_{\mathrm{c}} \leq \mathrm{F}_{\text {pasture }}\right)$, then the agent does not need to buy fodder, thus $\mathrm{F}_{\text {input }}=0 . \mathrm{Q}_{\mathrm{s}}$ is the larger one between $\mathrm{Q}_{1}$ and the amount determined by cash need $\left(\mathrm{I}_{\mathrm{t}} / \mathrm{P}_{\mathrm{s}_{\mathrm{au}}}\right)$. The amount of loan to borrow is determined by formula 7 as described in the previous section. If there is not enough fodder on pastures for the cold season, then extra sheep have to be sold in addition to $\mathrm{Q}_{1}$. The $\mathrm{Q}_{\mathrm{s}}$ could be solved from the equation:

$$
Q_{s} \cdot P_{S_{-a u}}=I_{t}+\left(\left(N_{h}-Q_{s}\right) \cdot \varepsilon \cdot D_{c}-F_{\text {pasture }}\right) \cdot P_{f_{-} a u}
$$

in which the left is gross income from sheep sale, and the right is the total expenditures, including the costs of purchasing fodder. The amount of fodder input equals fodder gap $\left(\left(\mathrm{N}_{\mathrm{h}}-\mathrm{Qs}\right) \cdot \varepsilon \cdot \mathrm{Dc}-\right.$ $\mathrm{F}_{\text {pasture }}$. The amount of loan to borrow is determined by formula 7 as well.

\section{Decisions with the 'import of fodder only in disaster years' (IFDY) strategy}

If the 'import of fodder only in disaster years' (IFDY) strategy is adopted, the agent has to follow two additional constrictions: (1) do not input fodder in normal years, (2) input fodder is 
allowed in disaster years under the pre-condition that the number of breeding ewe do not increase. Therefore, if the year in question is not a disaster year, then the decision is the same as with the NIF strategy. If the year is a disaster year, the decision will be further determined by the supply and demand of fodder. If there are enough forage on pastures for cold season, then there's no need to buy fodder, thus $F_{\text {input }}=0 ; Q_{s}$ is the biggest one among $Q_{1}$, the differences of current herd number $\left(\mathrm{N}_{\mathrm{h}}\right)$ and the number of ewes $\left(\mathrm{N}_{\mathrm{e}}\right)$ at the beginning of the year, and the number determined by cash need ( $\left.\mathrm{I}_{t} / \mathrm{P}_{\mathrm{s}_{-} a u}\right)$. Otherwise, $\mathrm{Qs}$ is determined by the number of breeding ewe at the beginning of the year, or the equation (1) in the appendix. Finput equals fodder gap. In any cases, the amount of loan to borrow is determined by formula 7 .

From the above processes, it is clear that the core step in stocking decision is to determine the number of livestock to sale. The amount of fodder input and loan to borrow are determined by the remaining number of livestock. 